This document is the Accepted Manuscript version of a Published Work that appeared in final form in the Journal of Organic Chemistry, copyright (C) American Chemical Society after peer review and technical editing by the publisher.

To access the final edited and published work see

Journal of Organic Chemistry 2020, 85, 13747-13756

\title{
https://doi.org/10.1021/acs.joc.0c01882
}

Also see same web-link for Supporting Information, available free of charge. 


\section{Catalytic Synthesis of}

\section{Luminescent Pyrimidines via}

\section{Acceptorless Dehydrogenative}

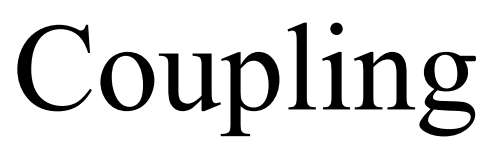

Rajarshi Mondal, Issiah B. Lozada, Olha Stotska and David E. Herbert*

Department of Chemistry and the Manitoba Institute for Materials

University of Manitoba, 144 Dysart Road, Winnipeg, Manitoba, R3T 2N2, Canada

*david.herbert@umanitoba.ca 


\begin{abstract}
A simple catalytic synthesis of luminescent pyrimidines from benzamidines and alcohols is reported. These one-pot, acceptorless dehydrogenative coupling reactions are catalyzed by a ruthenium hydrido chloride complex (1), supported by a chelating $P^{\wedge} N$ ligand (L1) bearing a benzannulated phenanthridine donor arm. The pyrimidines thus produced are emissive in solution, with photoluminescence quantum yields (PLQY) reaching 72\%. Details of the catalytic synthesis and characterization of the pyrimidines in both solution and the solid-state is reported, along with computational modelling of the emissive excited states of representative examples.
\end{abstract}




\section{INTRODUCTION}

Pyrimidines, long recognized for their critical role in biological processes, ${ }^{1}$ have been increasingly considered for applications in medicinal chemistry ${ }^{2,3}$ and as photo-emissive materials. ${ }^{4}$ With respect to their photophysical properties, thanks to the presence of two electronegative nitrogen atoms, pyrimidines can serve as the electron-withdrawing core of donoracceptor-donor (D-A-D) or donor-acceptor-acceptor (D-A-A) triads, or as a terminus in asymmetric (D-A) variants. ${ }^{5}$ In these systems, the pyrimidine unit stabilizes the lowest unoccupied molecular orbital (LUMO), helping to facilitate charge-transfer within the molecule and enable their use as electron transport materials. ${ }^{6}$ Such push-pull molecules are also sought as low band-gap materials for applications including light emitting diodes (LEDs), ${ }^{7}$ photovoltaic devices $^{8-10}$ and organic electronics. ${ }^{11}$

As with emissive molecule design in general, there has been expanded interest of late in straightforward and more sustainable preparatory routes to highly substituted, emissive pyrimidines. Moving away from metal-catalyzed cross-coupling methodologies for the derivatization of halogenated pyrimidines, ${ }^{12-19}$ for example, would obviate the production of halogenated waste. One-pot, coupling-isomerization sequences ${ }^{20}$ and modified Pinner condensations involving silylated amidines ${ }^{21}$ have been reported but similarly require functionalized precursors. In comparison, acceptorless dehydrogenative coupling (ADC) reactions of alcohols in the presence of benzamidine nucleophiles, variants of the so-called "indirect" Friedländer annulation, ${ }^{22}$ employ a single catalyst for both the oxidation of alcohols and their catalytic condensation with amidines. They can thus be used to prepare a variety of highly substituted pyrimidines with only hydrogen gas and water as byproducts. ${ }^{23-29} \mathrm{We}$ herein report the application of this synthetic methodology for the preparation of a series of emissive, push-pull 
pyrimidines (Figure 1). In addition to the catalytic preparation and full characterization of a series of novel pyrimidines, we furthermore describe their optical properties, along with computational modelling and solid-state structures of selected representatives, demonstrating the utility of ADC pathways for the preparation of asymmetric D-A-D' and D-A-A pyrimidine $\pi$-systems.

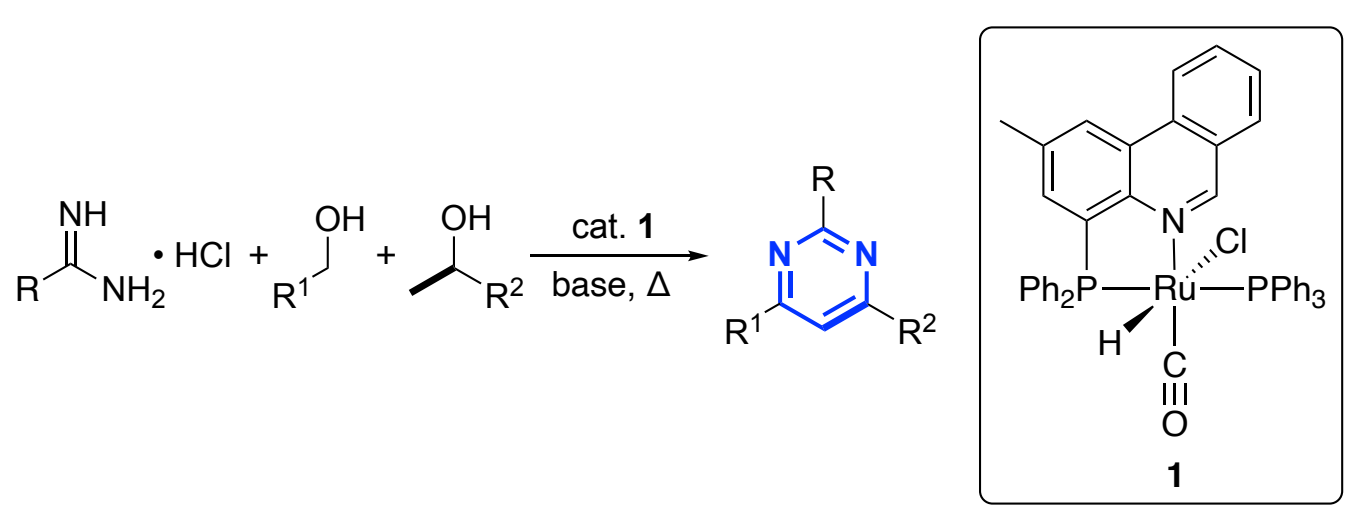

Figure 1. Multi-component synthesis of pyrimidines (core structure highlighted in blue) catalyzed by 1 .

\section{RESULTS AND DISCUSSION:}

While a number of catalytic routes to polysubstituted pyridines and quinolines via ADC mechanisms have been reported, only a limited number of homogeneous systems capable of the construction of pyrimidines have been disclosed..$^{23-28}$ We recently described the preparation and reactivity of a ruthenium hydrido chloride complex (1) supported by a simple, heteroleptic bidentate $P^{\wedge} N$ ligand containing a diarylphosphine and a benzannulated phenanthridine donor arm. ${ }^{30}$ In the presence of base, complex 1 efficiently catalyzes multi-component reactions using alcohol precursors to produce structurally diverse molecules including pyridines and quinolines. Notably, the ligand manifold in $\mathbf{1}$ does not bear readily (de)protonated Brønsted acidic or basic 
groups common to transition metal catalysts capable of these sorts of transformations, suggesting metal-ligand cooperativity does not play a significant role in the catalytic ADC-type reactivity of 1. Instead, formation of relatively stable and isolable $\eta^{2}$-aldehyde adducts are proposed to promote multicomponent reactions.

In that work, we also described the utility of $\mathbf{1}$ in the preparation of a limited selection of highly substituted pyrimidines in a one-pot ADC of benzamidine hydrochlorides, secondary alcohols and primary alcohols. Here, we extend this synthetic methodology to asymmetric emissive analogs (Table 1). Using previously optimized reaction conditions, ${ }^{30}$ benzamidine hydrochloride, a secondary alcohol and a primary alcohol were combined with $0.5 \mathrm{~mol} \%$ of 1 in the presence of a base $(\mathrm{KO} t \mathrm{Bu})$ and heated in an open reflux in dry toluene for $24 \mathrm{~h}$. In this way, a library of 17 novel emissive pyrimidines (P1-4) was prepared. The catalysis tolerates inclusion of a methyl substituent at the para-position of the benzamidine precursor, which can furthermore be used as its more conveniently handled hydrochloride salt when an extra equivalent of base is introduced. The reaction conditions similarly tolerate a variety of functionalized alcohols, including those bearing methoxy, dimethyl and diphenyl amino, thiophene and terthiophene substituents, as well as carbazoles and extended pyrenyl and anthracenyl $\pi$-systems. For the secondary alcohols, slightly higher yields were observed with electron-poor biphenyl derivatized precursors compared with electron-rich methoxynapthyls. In terms of primary alcohols, the presence of electron-rich donor functionalities as in $\mathbf{P 2 f}$ led to moderately higher isolated yields. While the yields are fair to moderate, the pyrimidines are easily isolated in their pure forms following column chromatography on silica, including on larger, millimolar scales (see Experimental Section). Notably, asymmetric D-A-D' and D-A-A systems could be produced in one pot without requiring multi-step sequences of the sort common in the literature. ${ }^{31}$ 
Table 1. Preparation of emissive pyrimidines P1-4 via acceptorless dehydrogenative coupling catalyzed by 1 .
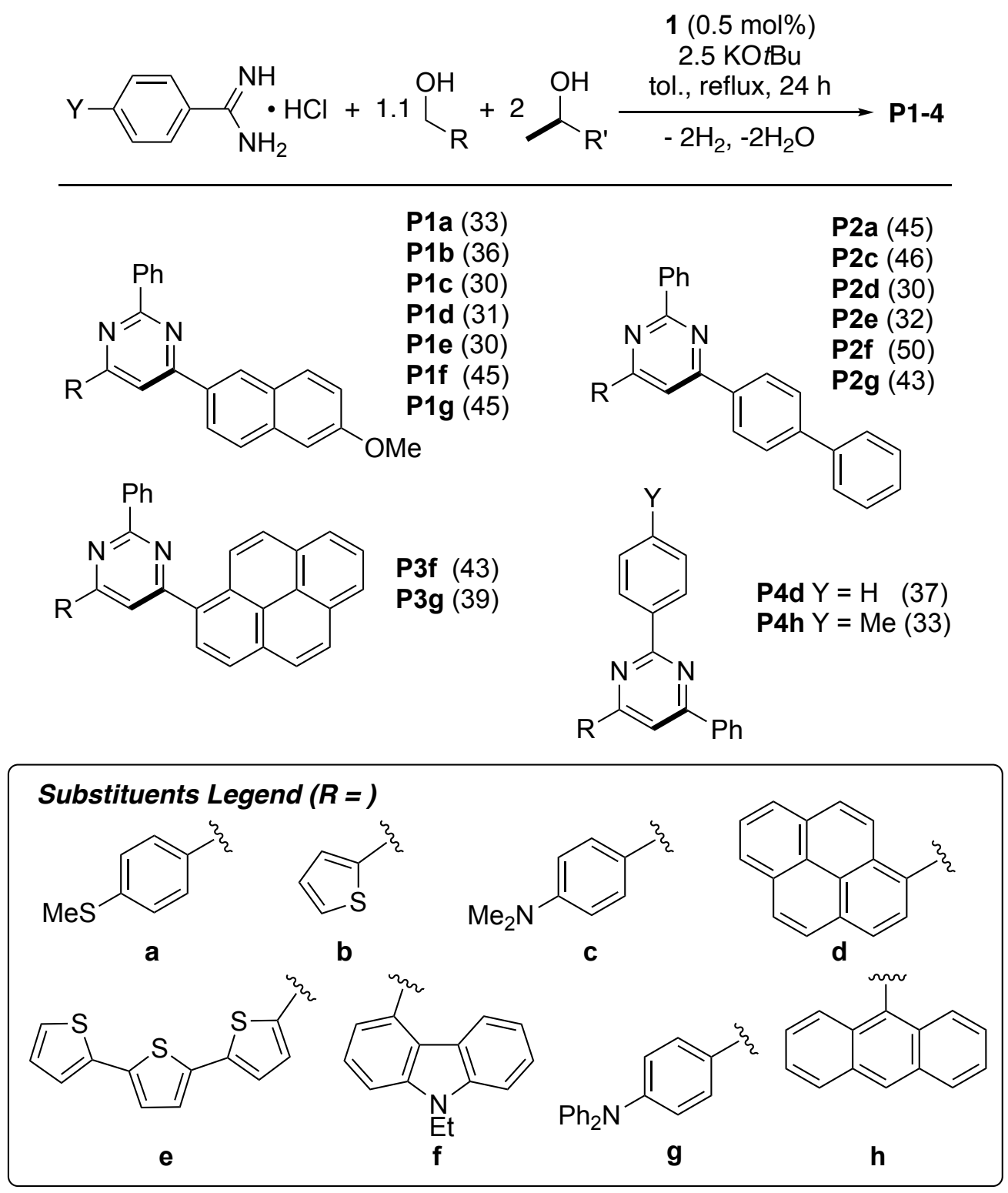

The pyrimidines thus produced were characterized in solution using both ${ }^{1} \mathrm{H}$ and ${ }^{13} \mathrm{C}$ NMR, with the exception of the terthiophene-substituted P1e for which a meaningful ${ }^{13} \mathrm{C}$ NMR spectrum could not be obtained due to poor solubility. In each case, formation of the central pyrimidine core was confirmed by observation of a distinctive singlet $\mathrm{CH}$ resonance in the aromatic region of the ${ }^{1} \mathrm{H}$ NMR spectrum just downfield of $8 \mathrm{ppm}$. High-resolution mass spectrometry (HRMS) was 
further used to establish product identity. To confirm the solution-state connectivity, solid-state structures for two (para-amino)phenyl-substituted products, P1c and P3g, were obtained using single-crystal X-ray diffraction (Figure $\mathrm{S} 1$ ). The formation of the $\left[\mathrm{N}_{2} \mathrm{C}_{4}\right]$ ring is readily apparent and its aromatic character can be deduced from the shorter $\mathrm{C}-\mathrm{C}$ bond distances within the ring $[\mathrm{C} 2$ -

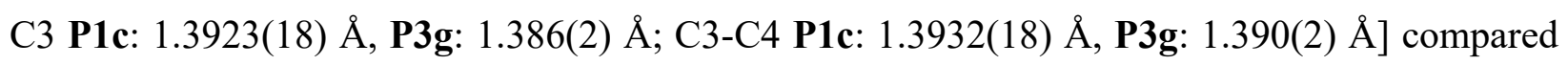

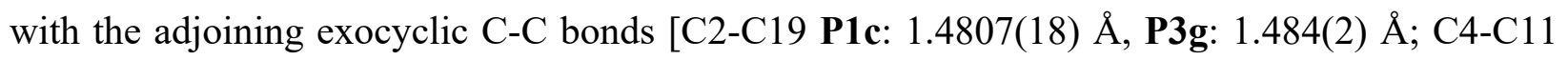
P1c: $1.4719(18) \AA$, P3g: $1.476(2) \AA]$. In the solid-state, the phenyl $\left(15^{\circ}\right)$ and naphthyl $\left(38^{\circ}\right)$ substituents of $\mathbf{P 1 g}$ are twisted with respect to the plane of the pyrimidine core. In P3g, the corresponding values are phenyl $\left(21^{\circ}\right)$ and pyrenyl $\left(52^{\circ}\right)$. The para-dimethylamino unit, however, is nearly planar in $\mathbf{P 1 g}$ with a sum of bond angles about N3 of $357^{\circ}$. In P3g, the corresponding sum of bond angles about the N3 of the diphenylamino unit $\left(360^{\circ}\right)$ is similarly indicative of conjugation of the amino lone pair into the pyrimidine acceptor core.

The mechanism of formation of P1-4 is anticipated to mirror that involved in the catalytic formation of non-emissive analogs mediated by $1,{ }^{30}$ which shows key differences from ADC-type mechanisms for pyrimidine formation catalyzed by other transition metal complexes, namely in the lack of observation of unsaturated chalcone intermediates proposed to play a central role in the formation of pyrimidines from alcohols. ${ }^{29,26}$ While related catalysts based on Mn have been demonstrated to effectively catalyze one-pot, four-component reactions in which $\beta$-alkylation of a secondary alcohol by a primary alcohol is followed by addition of a different primary alcohol and an amidine to produce even more complex pyrimidines, ${ }^{25}$ we have so far been unable to access similar reactivity with $\mathbf{1}$. 


\section{Absorption and Emission Spectra}

Pyrimidines P1-4 were next characterized by steady-state absorption and emission spectroscopy in air-saturated $\mathrm{CH}_{2} \mathrm{Cl}_{2}$ solutions at $298 \mathrm{~K}$. The pertinent photophysical data is shown in Figures 2-3 and summarized in Table 2. In solution, all 17 pyrimidines absorb strongly in the UV region; only the lowest energy absorption manifold of P1e and P2e extend meaningfully into the visible. For the most part, the absorption profiles are broad and featureless. The exception is the anthracenyl-bearing P4h (Figure 3b) which shows vibrational sub-levels with frequency differences between the sublevels of $1341 \mathrm{~cm}^{-1}$ and $1405 \mathrm{~cm}^{-1}$, consistent with those found in anthracene itself. ${ }^{32}$ Thus, for $\mathbf{P 4 h}$ electronic excitation between $349-386 \mathrm{~nm}$ results in population of anthracene $\pi^{*}$-orbitals. Otherwise, the absorption profiles are unremarkable compared to those reported for other pyrimidine-based dyes. ${ }^{19,33}$
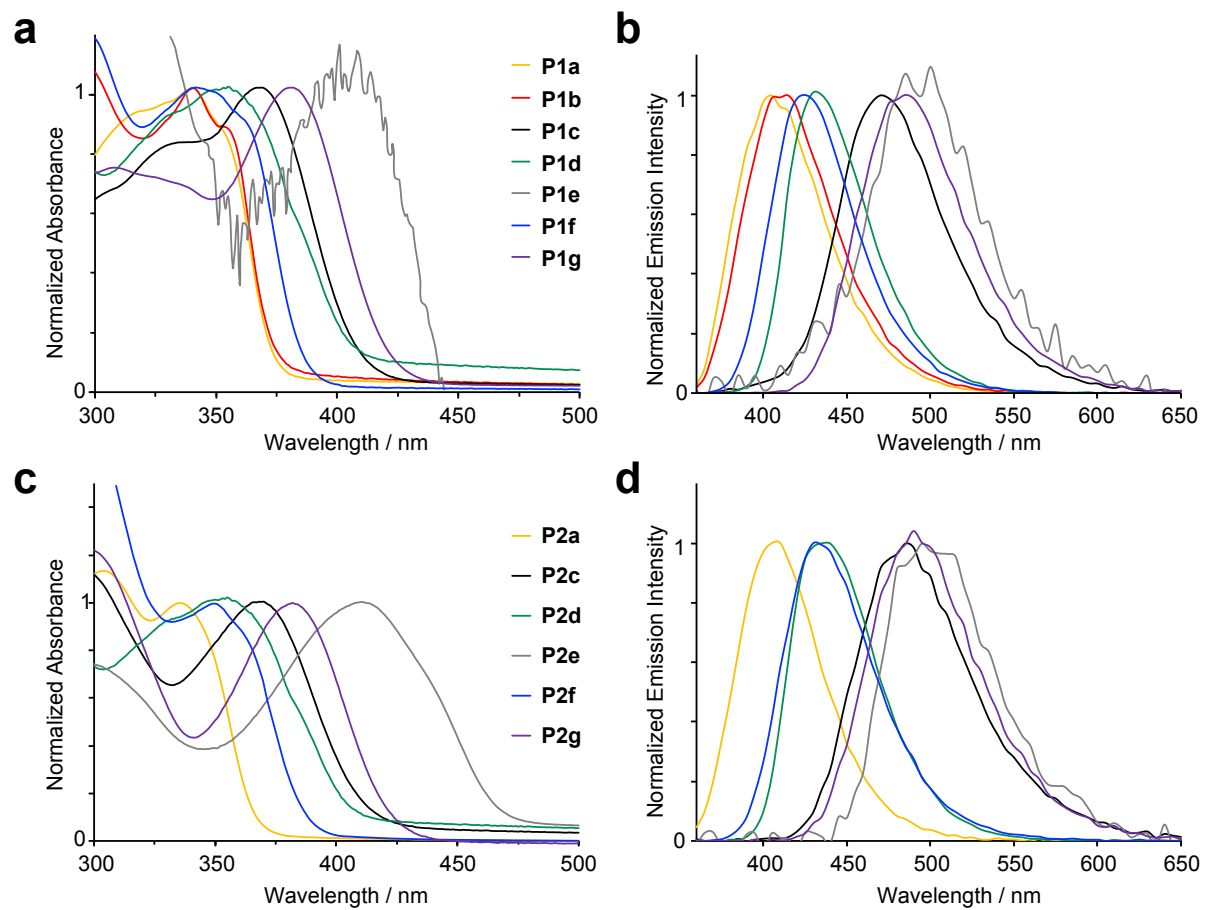

Figure 2. (a) UV-Vis absorption and (b) steady-state emission spectra of P1a-g; and (c) UV-Vis absorption and (d) steady-state emission spectra of P2a-g in $\mathrm{CH}_{2} \mathrm{Cl}_{2}$ at $298 \mathrm{~K}$. Molar extinction coefficients $\left(\varepsilon / \mathrm{M}^{-1} \mathrm{~cm}^{-1}\right)$ are provided in Tables 2 and S1-S4. 
Table 2. UV-Vis and photoluminescence properties of $\mathbf{P 1 - 4}$ in $\mathrm{CH}_{2} \mathrm{Cl}_{2}$ at $298 \mathrm{~K}$.

\begin{tabular}{|c|c|c|c|c|}
\hline Compound & $\begin{array}{c}\lambda_{\mathrm{abs}, \max } / \mathbf{n m} \\
\left(\varepsilon / \mathbf{M}^{-1} \mathbf{c m}^{-1}\right)^{a}\end{array}$ & $\begin{array}{c}\lambda_{\text {em,max }} / \mathbf{n m} \\
\left(\Phi_{\mathbf{F}} / \%\right)^{a}\end{array}$ & $\begin{array}{c}\underset{\mathrm{FWHM}_{\mathrm{em}}{ }^{b} /}{\mathrm{cm}^{-1}} \\
\end{array}$ & $\begin{array}{c}\text { Stokes shift } / \mathrm{cm}^{-1} \\
(\mathrm{~nm})\end{array}$ \\
\hline P1a & $340(32683)$ & $400(27)$ & 4874 & $4412(60)$ \\
\hline P1b & $340(22361)$ & $412(7)$ & 5652 & $5140(72)$ \\
\hline P1c & $367(30005)$ & $478(48)$ & 2073 & $6327(111)$ \\
\hline P1d & $355(15615)$ & $431(70)$ & 4046 & $4888(75)$ \\
\hline P1e & 409 (496) & $486(4)$ & 2050 & $3874(77)$ \\
\hline P1f & $342(34131)$ & $422(61)$ & 2189 & $5543(80)$ \\
\hline P1g & $381(71654)$ & $488(72)$ & 5864 & $5824(108)$ \\
\hline $\mathbf{P} 2 \mathbf{a}$ & $336(56323)$ & $411(32)$ & 1914 & $5431(75)$ \\
\hline P2c & $370(22467)$ & $495(25)$ & 2161 & 7046 (128) \\
\hline P2d & 355 (15934) & $435(46)$ & 2100 & $5997(90)$ \\
\hline P2e & $410(35850)$ & 497 (9) & 3618 & $4270(87)$ \\
\hline P2f & 349 (13894) & $432(66)$ & 5111 & $5423(82)$ \\
\hline P2g & $382(16070)$ & $497(36)$ & 1942 & $6057(115)$ \\
\hline P3f & $354(32718)$ & $445(63)$ & 4330 & $5777(91)$ \\
\hline P3g & $385(68320)$ & $514(30)$ & 2056 & $6586(130)$ \\
\hline P4d & $356(20625)$ & $432(72)$ & 4168 & $4863(75)$ \\
\hline P4h & $367(8010)$ & $457(38)$ & 2231 & $5366(71)$ \\
\hline
\end{tabular}

${ }^{a}$ Fluorescence quantum yield determined relative to quinine sulfate in $0.05 \mathrm{M} \mathrm{H}_{2} \mathrm{SO}_{4}$ as the standard $\left(\Phi_{\mathrm{F}}=0.52\right)$; excitation at $\lambda=350 \mathrm{~nm}$; entrance/exit slit width $=2 \mathrm{~nm} .{ }^{b}$ Estimated using an asymmetric pseudo-Voigt fitting function as described in reference ${ }^{34}$.

Looking into the influence of substituents, a bathochromic shift in the absorbance maximum is observed when increasingly electron-releasing substituents are introduced at the donor fragment. For example, when the thioether substituent in P1a or P2a is replaced with stronger amine donors (P1c/P1g, P2c/P2g). This is consistent with HOMO destabilization resulting from introduction of the stronger electron-donor moiety. ${ }^{5}$ This destabilization is particularly strong when the substituent is para to the pyrimidine; only a minor bathochromic shift is observed for P1f and P2f bearing a 9-ethylcarbazole in which the amine substituent is attached at the meta position. A similar dependence on the position of the electron-donor substituent is seen in $\lambda_{\max }$ of P3f, which is blueshifted compared to that of P3g. Replacing the thioether donor fragment in P1a with a thiophenederived substituent in $\mathbf{P 1 b}$ does not shift the absorbance band maximum, presumably due to the similarity of the Hammett values of methylthioether (0.00) and 2-thiophene (0.05) substituents. ${ }^{35}$ 
However, increasing the number of linked thiophenes at the donor fragment does induce a significant bathochromic shift (P1e and P2e) as the stronger electron donating ability of the more electron-rich terthiophene substituent ${ }^{36}$ destabilizes the HOMO and contracts the HOMO-LUMO gap. On the other hand, a hypsochromic shift is observed when comparing P4d $\left(\lambda_{\max }=357 \mathrm{~nm}\right)$ and P4h $\left(\lambda_{\max }=367 \mathrm{~nm}\right)$. This suggests that expansion of the aromatic donor fragment, from anthracene to pyrene, leads to HOMO stabilization and a larger HOMO-LUMO gap.

Violet-cyan fluorescence is observed from all 17 pyrimidines (Table 2) with maxima ranging from $400-514 \mathrm{~nm}$ and photoluminescence quantum yields of up to $72 \%$ measured in $\mathrm{CH}_{2} \mathrm{Cl}_{2}$ solution at $25{ }^{\circ} \mathrm{C}$. Compared with other D-A-D' and D-A-A pyrimidines, ${ }^{20,30}$ the Stokes shifts can be quite narrow (e.g., $60 \mathrm{~nm}$ for P1a) and the fluorescence quantum yields robust, for example, reaching up to $\sim 70 \%$ for P1d, P1g and P4d. Within the library, similar trends are observed in emission as in absorption: strong donors and benzannulation at the donor fragment results in bathochromic and hypsochromic shifts, respectively, in the emission maxima. The most red-shifted emission is seen from P3g $\left(\lambda_{\mathrm{em}}=514 \mathrm{~nm}\right)$, which accordingly exhibits the largest Stokes shift $(130 \mathrm{~nm})$. This, however, does not correlate strongly with the emission quantum yield as some of the stronger emitters ( $\Phi_{\mathrm{F}}>60 \%$; e.g., P1d, P1f, P1g, P2f, P3f and P4d) have variable Stokes shift ranging from $75 \mathrm{~nm}(\mathbf{P 1 d}$ and P4d) to $108 \mathrm{~nm}(\mathbf{P 1 g})$. The sulfur-containing compounds $\mathbf{P 1 a} / \mathbf{P 1 b} / \mathbf{P 1 e}$ and $\mathbf{P 2 a} / \mathbf{P 2 e}$ exhibit the lowest quantum yields, possibly due to competing non-radiative photo-induced electron transfer, ${ }^{37}$ though other competing non-radiative pathways are possible. The highest quantum yields $(\sim 70 \%)$ are generally observed for pyrimidines bearing pyrene, 9-ethylcarbazole, and diphenylamine donors. On the whole, the fluorescence quantum yields measured for this series exceed those reported for similarly fluorescent pyrimidines found in the literature. ${ }^{4,19,33}$ 
Comparing a representative sample (P3g) in its solid form and in dichloromethane solution, a stark change from yellow (solid; Figure S2) to colorless (in solution) can be readily discerned by eye, indicating a sensitivity to the surrounding environment that is consistent with charge-transfer character to its excitation. ${ }^{38}$ Air-saturated solutions of P1c/P1d/P1g, P2c/P2d/P2g, P3g, and P4d in a variety of solvents were accordingly prepared to investigate the influence of solvent polarity on absorption and emission. In general, bathochromic shifts are observed in both the lowest absorbance band and emission wavelength in solvents of increasing polarity, with the impact on emission more pronounced (Figure 3c-d; Table S1-S4, Figures S3-S17). Interestingly, emission spectra in cyclohexane show vibrational fine structure not apparent in the broader, red-shifted emission in more polar solvents. This is consistent with operation of a locally excited (LE) state in addition to a charge-transfer one in the apolar cyclohexane environment. ${ }^{39,40}$ The bathochromic shift observed with increasing solvent polarity and consolidation of the emission peak into a single band indicates the emissive LE state is destabilized relative to the intramolecular charge-transfer state (ICT). These are further accompanied by larger Stokes shifts in solvents of increasing polarity, pointing to significant intra- and intermolecular reorganization to the lowest vibrational state of the emitting excited state. Consistent with these observations, calculated $\mu_{\mathrm{e}} / \mu_{\mathrm{g}}$ ratios indicate a significant increase in the dipole moment of the excited state (Tables S5-S6). 
a

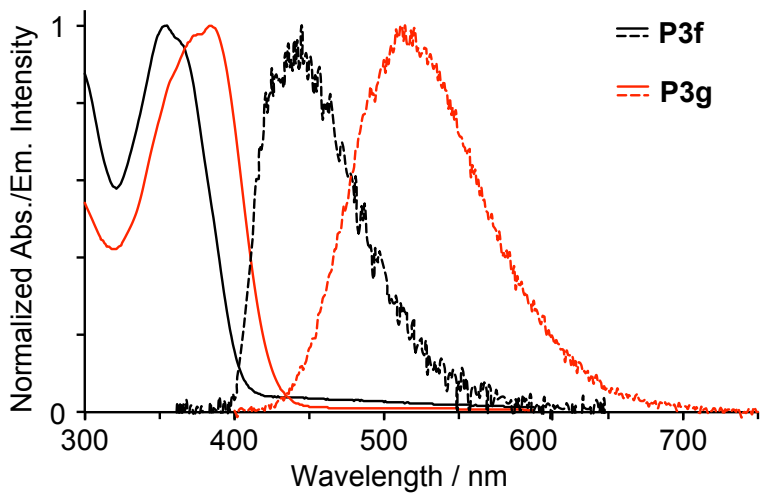

C

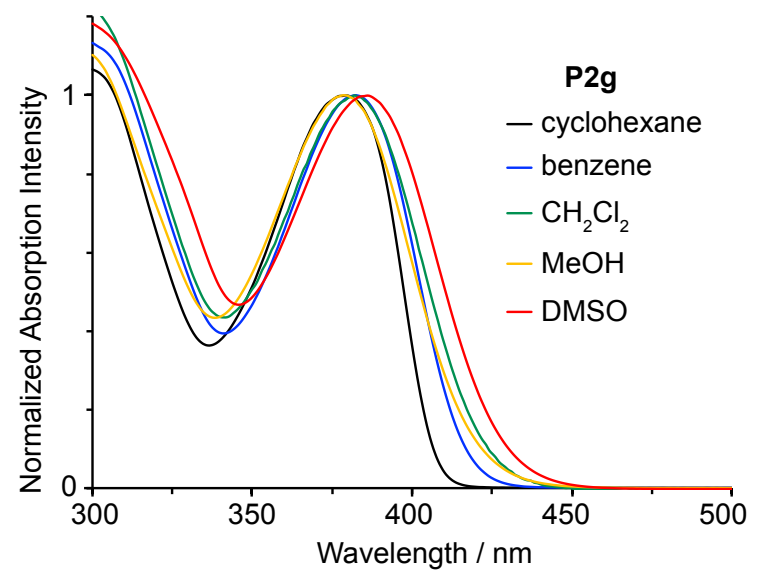

b

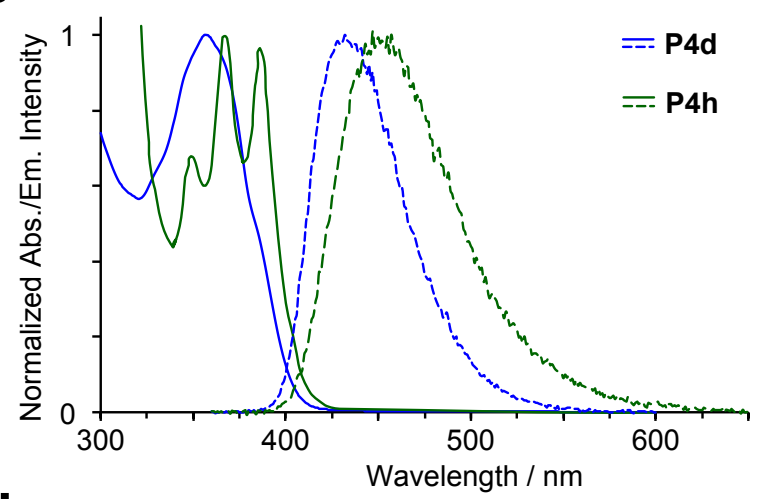

d

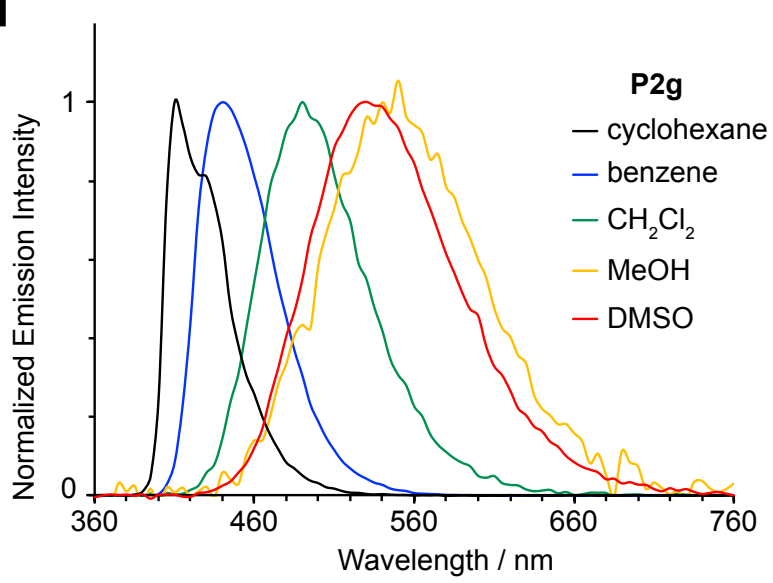

Figure 3. (a) UV-Vis absorbance (solid line) and emission (dashed line) spectra of P3f (black) and P3g (red) in $\mathrm{CH}_{2} \mathrm{Cl}_{2}$ solution; (b) UV-Vis absorbance (solid line) and emission (dashed line) spectra of $\mathbf{P 4 d}$ (blue) and $\mathbf{P 4 h}$ (green) in $\mathrm{CH}_{2} \mathrm{Cl}_{2}$ solution; (c) UV-Vis absorbance and (d) emission spectra of P2g in different solvents. Molar extinction coefficients $\left(\varepsilon / \mathrm{M}^{-1} \mathrm{~cm}^{-1}\right)$ are provided in Tables 2 and S1-S4.

\section{Electronic Structure Calculations}

Density functional theory (DFT) optimizations of pyrimidines P1c and P3g were carried out to further probe the electronic structures and understand the photophysical properties of two representative pyrimidines. Optimized ground-state bond lengths of the two compounds with 
IEFPCM $\left(\mathrm{CH}_{2} \mathrm{Cl}_{2}\right)$-B3LYP-D3(BJ)/6-311G(d,p) show only minor differences compared to the solid-state structures (Figures S18 and S19), though torsional angles about the rotatable single bonds do decrease in the optimized structures of both molecules. The observed flattening of the phenyl and pyrimidine fragment planes appears to be due to an interaction between the $\mathrm{CH}$ (phenyl) at the ortho-position and pyrimidine nitrogen. Other noted differences include an increase to the p-orbital character of the dimethylamine nitrogen in P1c; the smallest C-N-C angle in the $\mathrm{NMe}_{2}$ fragment increases from $114.1^{\circ}$ in the solid-state structure to $119.0^{\circ}$ in the optimized structure, for example. In contrast, there is a slight increase in the torsional angle about the N(diphenyl)$\mathrm{C}$ (phenyl) single bond in the optimized structure of $\mathbf{P 3 g}$, which minimizes intramolecular steric repulsion without affecting the $\mathrm{sp}^{2}$-hybridization of the diphenylamine nitrogen.

Ground-state frontier molecular orbitals from single point calculations are presented in Figure 4. Isosurfaces of these orbitals suggest D-A-D' (P1c) and D-A-A (P3g) character, respectively, to the lowest energy absorptions. Consistent with the observed red-shift to the UVVis absorbances of P3g compared with those of P1c, P3g has a smaller HOMO-LUMO gap. TDDFT simulated spectra match the experimental spectra of both compounds (Figures S20 and S21). More than one transition contributes to the lowest energy UV-Vis band for both compounds. The strongest transition in P1c (Table S7) is nevertheless dominated by a HOMO $\rightarrow$ LUMO excitation (85\%), and has strong CT character as a result. Configuration interaction complicates assignment of the dominant states in P3g. Three orbital pairs contribute significantly (contribution $>10 \%)$ to the lowest excited state (Table S8). The HOMO $\rightarrow$ LUMO $(45 \%)$ and the $\mathrm{HOMO} \rightarrow \mathrm{LUMO}+1$ transition $(15 \%)$ both present significant electron redistribution, again consistent with CT character. In comparison, the third contributing transition (HOMO-1 $\rightarrow$ LUMO, $24 \%$ ) has $\pi-\pi^{*}$ character localized in the pyrenyl fragment. Overall, this state still largely is CT in 
character, consistent with the observed solvatochromism and solvatofluorochromism. In accordance with the orbital character to the HOMO, cyclic voltammograms of both P1c and P3g show (quasi)reversible oxidations consistent with generation of aminyl radicals (Figure S22, Table S9) that are more reversible for the more sterically protected diphenylamine in P3g.

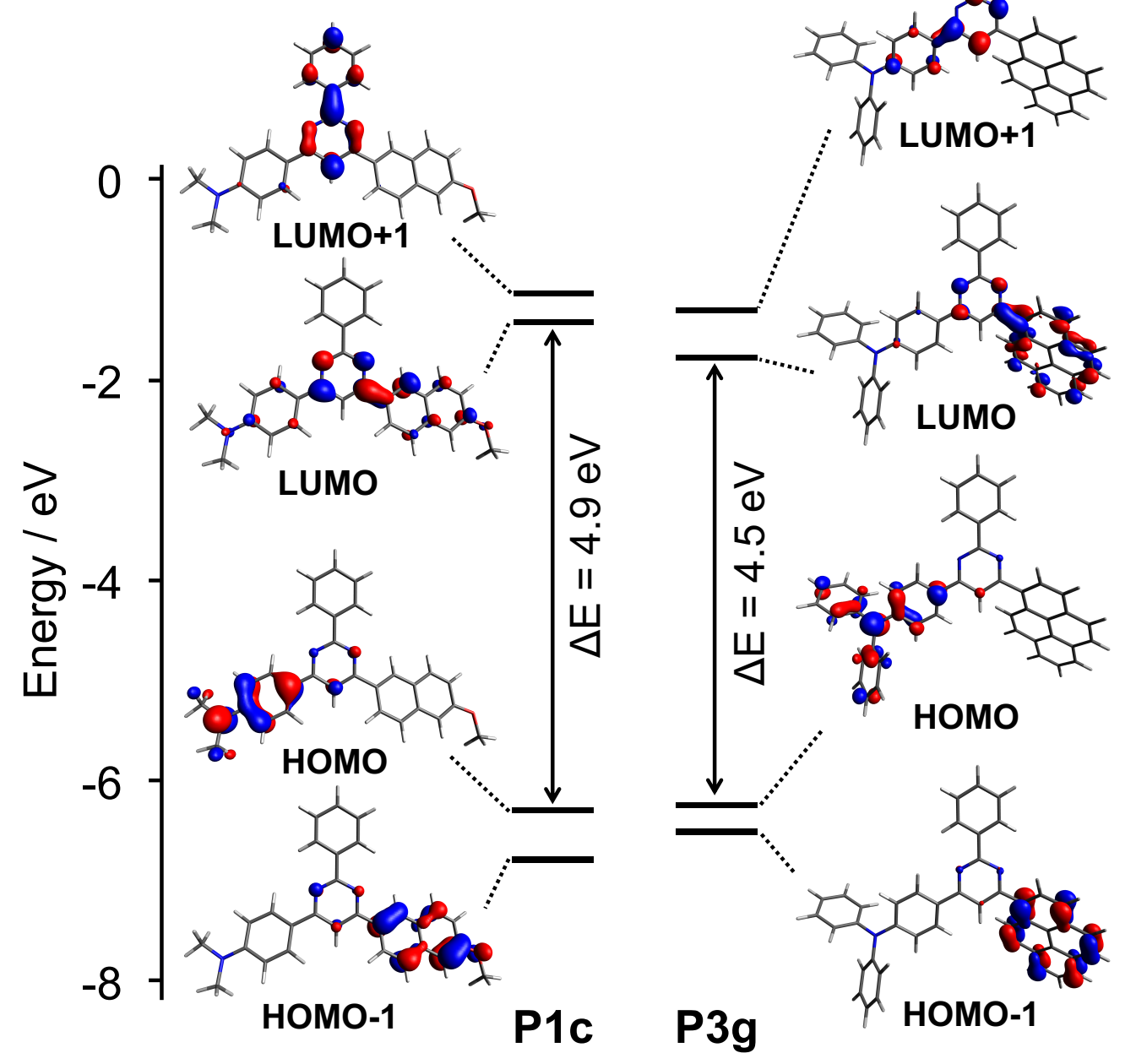

Figure 4. Frontier molecular orbital topologies (IEFPCM-MN15/6-311+G(d,p)//IEFPCMB3LYP-D3(BJ)/6-311G(d,p); isosurface value = 0.05) of D-A-D' P1c and D-A-A P3g. 


\section{CONCLUSIONS}

The synthesis of a novel library of 17 asymmetric D-A-D' and D-A-A luminescent pyrimidines is presented, along with their photophysical characterization. The series of complexes were prepared in one-pot ADC-type reactions using a phenanthridine-based $P^{\wedge} N$-supported Ru complex (1), with only water and hydrogen as byproducts. The new pyrimidines absorb to the high energy edge of the visible and emit cyan-violet light with emission wavelength maxima ranging from 400-514 $\mathrm{nm}$, depending on the substitution pattern. With quantum yields measured in solution of up to $72 \%$, and tuneable frontier orbital energies, these emissive materials suggest promising applications in organic optoelectronics. Investigations to this is extent are currently underway.

\section{EXPERIMENTAL DETAILS}

\section{General Experimental Information}

Air sensitive manipulations were carried out under inert atmosphere in either a glove box $\left(\mathrm{N}_{2}\right)$ or using standard Schlenk techniques (Ar). Reactants and reagents used in catalytic reactions were similarly purchased from various chemical vendors as reagent grade or better and used as received (when solids) or stored over dry molecular sieves (when liquids) prior to use. 4diphenylphosphino-2-methylphenanthridine, ${ }^{41} \mathbf{1 , 3 0}$ (9-ethyl-9H-carbazol-4-yl)methanol and 4(diphenylamino)phenyl)methanol, ${ }^{42}$ 4-(dimethylamino)phenyl)methanol and 2,2':5',2"-terthiophene-5-methanol ${ }^{43}$ were synthesized following published procedures. Organic solvents were dried over appropriate reagents and deoxygenated prior to use, except for 1,2-dimethoxyethane, water and 2-methoxyethanol, which were simply degassed. NMR spectra (Figures S23-S55) were 
recorded on a Bruker Avance $300 \mathrm{MHz}$ or Bruker Avance-III $500 \mathrm{MHz}$ spectrometer as noted. High-resolution mass spectra (Figures S56-S72) were collected using a Bruker microOTOF-QIII. Solution samples for absorption and emission spectroscopies were prepared under ambient, oxygen saturated conditions in $\mathrm{CH}_{2} \mathrm{Cl}_{2}$ in 10 x $10 \mathrm{~mm}^{2}$ quartz cuvettes. Solvatochromism and solvatofluorochromism were examined by dissolving P1c/P1d/P1g, P2c/P2d/P2g, P3g, and P4d in different solvents of increasing polarity: cyclohexane, benzene, $\mathrm{THF}, \mathrm{CH}_{2} \mathrm{Cl}_{2}, \mathrm{MeOH}, \mathrm{CH}_{3} \mathrm{CN}$, and DMSO. Absorbance and emission spectra were collected on a Cary 5000 UV-Vis NIR spectrophotometer and a PTI QM30 fluorimeter ( $2 \mathrm{~nm}$ slit widths, $\lambda_{\mathrm{exc}}=350 \mathrm{~nm}$ ). Fluorescence quantum yields were measured using quinine sulfate as standard. The FWHM of the fluorescence peaks were estimated using an asymmetric fitting function. ${ }^{34}$ All calculations were carried out using Gaussian 16, Rev. B.01. ${ }^{44}$ Solvent effects, using $\mathrm{CH}_{2} \mathrm{Cl}_{2}$, were included implicitly using IEFPCM. ${ }^{45}$ Intramolecular interactions were accounted for using Grimme's D3 empirical dispersion with Becke-Johnson damping. ${ }^{46}$ Structures for P1c and P3g were optimized using the B3LYP functional ${ }^{47,48}$ and 6-311G(d,p) basis set on all atoms. ${ }^{49}$ The B3LYP functional has been shown previously to reproduce the solid-state structures of similar pyrimidine compounds. ${ }^{19}$ The MN15 functional ${ }^{50}$ with $6-311+\mathrm{G}(\mathrm{d}, \mathrm{p})$ basis $\operatorname{set}^{49,51}$ for all atoms were used to accurately estimate the first 50 vertical excitation energies within the time-dependent DFT (TDDFT) formalism, which should be enough to cover the $300-600 \mathrm{~nm}$ range of the spectrum. Functionals with large amounts of HF especially in the long range have been proposed to accurately estimate charge transfer transition energies. ${ }^{52}$ Optical spectra were simulated using the GaussSum software package. ${ }^{53}$ All structures and molecular orbitals (MOs) were generated with Avogadro. ${ }^{54}$ 


\section{Synthesis and Characterization of Pyrimidines}

General Procedure: A $50 \mathrm{~mL}$ Schlenk flask was charged with benzamidine hydrochloride $(0.156$ $\mathrm{g}, 1.00 \mathrm{mmol}), \mathrm{KO} t \mathrm{Bu}(0.280 \mathrm{~g}, 2.50 \mathrm{mmol})$ and dry toluene $(3 \mathrm{~mL})$ inside an $\mathrm{N}_{2}$-filled glove box and the mixture stirred for $15 \mathrm{~min}$. Subsequently, a primary alcohol $(1.10 \mathrm{mmol})$, secondary alcohol (2.00 mmol) and 1 (0.004 g, $0.005 \mathrm{mmol} ; 0.5 \mathrm{~mol} \%)$ were added, followed by an additional $5 \mathrm{~mL}$ of toluene. The flask was then removed from the glove box, connected to a condenser under Ar atmosphere, and heated to reflux as an open system in an oil bath set heated to $130{ }^{\circ} \mathrm{C}$. After $24 \mathrm{~h}$, the mixture was cooled and filtered through a short plug of silica $(\sim 1 \mathrm{~cm})$ using $\mathrm{CH}_{2} \mathrm{Cl}_{2}$-hexanes. Isolated yields are reported following column chromatography on silica.

4-(6-methoxynaphtalen-2-yl)-6-(4-methylthio)phenyl)-2-phenylpyrimidine (P1a): The silica column was performed using $\mathrm{CH}_{2} \mathrm{Cl}_{2} /$ hexanes 7:3 $\left(\mathrm{R}_{\mathrm{f}}=0.80\right)$. Yellow solid. Isolated yield $=0.143$ $\mathrm{g}(33 \%) .{ }^{1} \mathrm{H} \mathrm{NMR}\left(\mathrm{CDCl}_{3}, 300 \mathrm{MHz}, 22{ }^{\circ} \mathrm{C}\right): \delta 8.76-8.73(\mathrm{~m}, 2 \mathrm{H}), 8.68(\mathrm{~s}, 1 \mathrm{H}), 8.36-8.33(\mathrm{~m}$, 1H), 8.26-8.23 (m, 2H), $8.04(\mathrm{~s}, 1 \mathrm{H}), 7.93-7.86(\mathrm{~m}, 2 \mathrm{H})$, 7.57-7.55 (overlapped m, 3H), 7.42-7.39 (m, 2H), 7.24-7.19 (m, 2H), $3.96(\mathrm{~s}, 3 \mathrm{H}), 2.57 \mathrm{ppm}(\mathrm{s}, 3 \mathrm{H}) .{ }^{13} \mathrm{C}\left\{{ }^{1} \mathrm{H}\right\} \mathrm{NMR}\left(\mathrm{CD}_{2} \mathrm{Cl}_{2}, 75 \mathrm{MHz}, 22\right.$ $\left.{ }^{\circ} \mathrm{C}\right): \delta 164.6,164.5,163.9,158.9,142.4,138.4,136.2,134.1,132.7,130.7,128.8,128.6,127.7$, 127.5, 127.3, 126.1, 124.9, 119.6, 109.6, 105.8, 55.5, 15.4 ppm. HR-MS(ESI+) m/z calcd. For $\left[\mathrm{C}_{28} \mathrm{H}_{22} \mathrm{~N}_{2} \mathrm{OS}+\mathrm{H}\right]^{+}$435.1526, found 435.1501.

4-(6-methoxynaphtalen-2-yl)-2-phenyl-6-(thiophen-2-yl)pyrimidine (P1b): The silica column was performed using $\mathrm{CH}_{2} \mathrm{Cl}_{2} /$ hexanes 1:1 $\left(\mathrm{R}_{\mathrm{f}}=0.60\right)$. White solid. Isolated yield $=0.142 \mathrm{~g}(36 \%)$. ${ }^{1} \mathrm{H}$ NMR $\left(\mathrm{CD}_{2} \mathrm{Cl}_{2}, 300 \mathrm{MHz}, 22{ }^{\circ} \mathrm{C}\right): \delta 8.71-8.68$ (overlapped $\left.\mathrm{m}, 3 \mathrm{H}\right), 8.36-8.33(\mathrm{~m}, 1 \mathrm{H})$, 7.997.89 (overlapped m, 4H), 7.60-7.55 (overlapped m, 4H), 7.25-7.20 (overlapped m, 3H), 3.94 ppm (s, 3H). ${ }^{13} \mathrm{C}\left\{{ }^{1} \mathrm{H}\right\} \mathrm{NMR}\left(\mathrm{CDCl}_{3}, 75 \mathrm{MHz}, 22{ }^{\circ} \mathrm{C}\right): \delta 164.9,164.7,160.1,159.5,144.0,138.4,136.7$, 
132.8, 131.3, 131.1, 130.4, 129.2, 128.9, 128.8, 127.9, 127.7, 125.2, 120.0, 108.7, 106.2, $55.9 \mathrm{ppm}$. HR-MS(ESI+) m/z calcd. For $\left[\mathrm{C}_{25} \mathrm{H}_{18} \mathrm{~N}_{2} \mathrm{OS}+\mathrm{H}\right]^{+}$395.1213, found 395.1194 .

$N, N$-Dimethyl-4-[6-(methoxynaphalen-2-yl)-2-phenyl-4-pyrimidinyl]benzenamine (P1c):

The silica column was performed using $\mathrm{CH}_{2} \mathrm{Cl}_{2}$ /hexanes 9:1 $\left(\mathrm{R}_{\mathrm{f}}=0.64\right)$. Light yellow solid. Isolated yield $=0.129 \mathrm{~g}(30 \%) .{ }^{1} \mathrm{H}$ NMR $\left(\mathrm{CDCl}_{3}, 500 \mathrm{MHz}, 22{ }^{\circ} \mathrm{C}\right): \delta 8.78(\mathrm{~m}, 2 \mathrm{H}), 8.69(\mathrm{~s}, 1 \mathrm{H})$, $8.35(\mathrm{~m}, 1 \mathrm{H}), 8.27(\mathrm{~m}, 2 \mathrm{H}), 8.00(\mathrm{~s}, 1 \mathrm{H}), 7.93-7.87(\mathrm{~m}, 2 \mathrm{H}), 7.59-7.51(\mathrm{~m}, 3 \mathrm{H}), 7.23-7.19(\mathrm{~m}$, 2H), 6.83 (m, 2H), $3.96(\mathrm{~s}, 3 \mathrm{H}), 3.07 \mathrm{ppm}(\mathrm{s}, 6 \mathrm{H}) .{ }^{13} \mathrm{C}\left\{{ }^{1} \mathrm{H}\right\} \mathrm{NMR}\left(\mathrm{CDCl}_{3}, 126 \mathrm{MHz}, 22{ }^{\circ} \mathrm{C}\right): \delta$ $164.5,164.3,163.9,158.8,152.4,138.9,136.0,133.3,130.7,130.4,128.9,128.6,128.5,128.4$ 127.4, 127.1, 125.0, 124.9, 119.5, 111.9, 108.5, 105.9, 55.5, 40.3 ppm. HR-MS(ESI+) m/z calcd. For $\left[\mathrm{C}_{29} \mathrm{H}_{25} \mathrm{~N}_{3} \mathrm{O}+\mathrm{H}\right]^{+} 432.2070$, found 432.2073 .

4-(6-methoxynaphtalen-2-yl)-2-phenyl-6-(pyren-1-yl)pyrimidine (P1d): The silica column was performed using $\mathrm{CH}_{2} \mathrm{Cl}_{2} /$ hexanes 3:7 $\left(\mathrm{R}_{\mathrm{f}}=0.64\right)$. White solid. Isolated yield: $0.158 \mathrm{~g}(31 \%)$. ${ }^{1} \mathrm{H} \mathrm{NMR}\left(\mathrm{CDCl}_{3}, 500 \mathrm{MHz}, 22{ }^{\circ} \mathrm{C}\right): \delta 8.82-8.80(\mathrm{~m}, 2 \mathrm{H}), 8.78(\mathrm{~s}, 1 \mathrm{H}), 8.72\left(\mathrm{~d}, J_{\mathrm{HH}}=10 \mathrm{~Hz}, 1 \mathrm{H}\right)$, 8.45-8.43 (m, 1H), 8.39-8.33 (m, 2H), 8.27-8.24 (m, 2H), 8.19-8.15 (overlapped m, 4H), 8.07 (m, $\left.J_{\mathrm{HH}}=10 \mathrm{~Hz}, 1 \mathrm{H}\right), 7.94-7.91(\mathrm{~m}, 2 \mathrm{H}), 7.60-7.55(\mathrm{~m}, 3 \mathrm{H}), 7.24-7.22(\mathrm{~m}, 2 \mathrm{H}), 3.98 \mathrm{ppm} .(\mathrm{s}, 3 \mathrm{H})$. ${ }^{13} \mathrm{C}\left\{{ }^{1} \mathrm{H}\right\} \operatorname{NMR}\left(\mathrm{CDCl}_{3}, 126 \mathrm{MHz}, 22{ }^{\circ} \mathrm{C}\right): \delta 167.8,164.7,164.4,159.1,138.4,136.4,134.1,132.6$, $132.5,131.5,131.0,130.9,130.8,129.1,128.9,128.8,128.7,128.6,127.7,127.5,126.4,125.9$, 125.6, 125.3, 125.0, 124.9, 124.8, 119.7, 115.9, 105.9, 55.6 ppm. HR-MS(ESI+) m/z calcd. For $\left[\mathrm{C}_{37} \mathrm{H}_{24} \mathrm{~N}_{2} \mathrm{O}+\mathrm{H}\right]^{+}$513.1961, found 513.1965.

\section{4-([2,2':5',2’'-terthiophen]-5-yl)-6-(6-methoxynaphtalen-2-yl)-2-phenylpyrimidine}

(P1e):

The silica column was performed using $\mathrm{CH}_{2} \mathrm{Cl}_{2}$ /hexanes 1:1 $\left(\mathrm{R}_{\mathrm{f}}=0.60\right)$. Yellow solid. Isolated yield $=0.168 \mathrm{~g}(30 \%) .{ }^{1} \mathrm{H} \mathrm{NMR}\left(\mathrm{CDCl}_{3}, 500 \mathrm{MHz}, 22{ }^{\circ} \mathrm{C}\right): \delta 8.73-8.71(\mathrm{~m}, 3 \mathrm{H}), 8.36-8.34(\mathrm{~m}$, 
1H), 7.94-7.85 (overlapped m, 4H), 7.58-7.53 (m, 3H), 7.28-7.27 (m, 2H), 7.24-7.15 (m, 5H), 7.05 (m, 1H), $3.98 \mathrm{ppm}(\mathrm{s}, 3 \mathrm{H})$. An informative ${ }^{13} \mathrm{C}\left\{{ }^{1} \mathrm{H}\right\}$ spectrum could not be obtained due to poor solubility at higher concentrations. HR-MS $(\mathrm{ESI}+) \mathrm{m} / \mathrm{z}$ calcd. For $\left[\mathrm{C}_{33} \mathrm{H}_{22} \mathrm{~N}_{2} \mathrm{OS}_{3}+\mathrm{H}\right]^{+} 559.0967$, found 559.0963 .

4-(6-(6-methoxynaphthalen-2-yl)-2-phenylpyrimidin-4-yl)-9-ethyl-9H-carbazole (P1f): The silica column was performed using $\mathrm{CH}_{2} \mathrm{Cl}_{2} /$ hexanes $1: 1\left(\mathrm{R}_{\mathrm{f}}=0.42\right)$. White solid. Isolated yield $=$ $0.220 \mathrm{~g}(45 \%) .{ }^{1} \mathrm{H} \mathrm{NMR}\left(\mathrm{CDCl}_{3}, 500 \mathrm{MHz}, 22{ }^{\circ} \mathrm{C}\right): \delta 9.08(\mathrm{~s}, 1 \mathrm{H}), 8.84-8.82(\mathrm{~m}, 2 \mathrm{H}), 8.77(\mathrm{~s}$, 1H), 8.51-8.49 (m, 1H), 8.44-8.42 (m, 1H), 8.31-8.29 (m, 1H), $8.23(\mathrm{~s}, 1 \mathrm{H}), 7.97-7.91(\mathrm{~m}, 2 \mathrm{H})$, 7.62-7.53 (m, 5H), 7.47-7.46 (m, 1H), 7.35-7.32 (m, 1H), 7.25- 7.22 (m, 2H), 4.45-4.41 (m, 2H), $3.98(\mathrm{~s}, 3 \mathrm{H}), 1.53-1.49 \mathrm{ppm}(\mathrm{m}, 3 \mathrm{H}) \cdot{ }^{13} \mathrm{C}\left\{{ }^{1} \mathrm{H}\right\} \mathrm{NMR}\left(\mathrm{CDCl}_{3}, 126 \mathrm{MHz}, 22{ }^{\circ} \mathrm{C}\right): \delta$ 165.5, 164.6, $164.5,158.9,141.9,140.8,138.8,136.2,133.2,130.7,130.6,128.9,128.7,128.6,127.5,127.3$, 127.3, 126.3, 125.4, 125.1, 123.6, 123.4, 120.9, 119.9, 119.7, 119.6, 109.8, 108.9, 108.8, 105.9, 55.5, 37.9, 14.0 ppm. HR-MS(ESI+) m/z calcd. For $\left[\mathrm{C}_{35} \mathrm{H}_{27} \mathrm{~N}_{3} \mathrm{O}+\mathrm{H}\right]^{+}$506.2227, found 506.2241.

N,N-Biphenyl-4-[6-(methoxynaphalen-2-yl)-2-phenyl-4-pyrimidinyl]benzenamine (P1g):

The silica column was performed using $\mathrm{CH}_{2} \mathrm{Cl}_{2} /$ hexanes 6:4 $\left(\mathrm{R}_{\mathrm{f}}=0.56\right)$. Light yellow solid. Isolated yield $=0.250 \mathrm{~g}(45 \%) .{ }^{1} \mathrm{H}$ NMR $\left(\mathrm{CDCl}_{3}, 500 \mathrm{MHz}, 2{ }^{\circ} \mathrm{C}\right): \delta 8.77-8.75(\mathrm{~m}, 2 \mathrm{H}), 8.70(\mathrm{~s}$, $1 \mathrm{H}), 8.37-8.35(\mathrm{~m}, 1 \mathrm{H}), 8.21-8.19(\mathrm{~m}, 2 \mathrm{H}), 8.02(\mathrm{~s}, 1 \mathrm{H})$, 7.92-7.88 (m, 2H), 7.57-7.49 (m, 3H), 7.35-7.32 (m, 4H), 7.24-7.20 (br overlapped m, 8H), 7.14-7.11 (m, 2H), $3.96 \mathrm{ppm}(\mathrm{s}, 3 \mathrm{H}) .{ }^{13} \mathrm{C}\left\{{ }^{1} \mathrm{H}\right\}$ $\operatorname{NMR}\left(\mathrm{CDCl}_{3}, 126 \mathrm{MHz}, 2{ }^{\circ} \mathrm{C}\right): \delta 164.5,164.2,158.9,150.5,147.3,138.6,136.1,132.9,130.7$, $130.6,129.6,128.9,128.6,128.5,128.4,127.5,127.2,125.4,124.9,123.9,122.3,119.6,109.4$

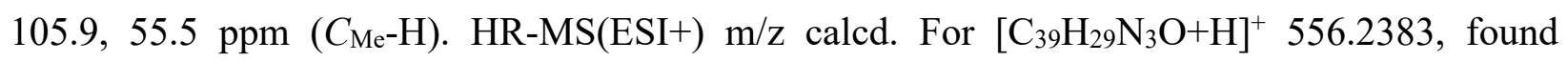
556.2397. 
6-(4-methylthiophenyl)-4-(6-[1,1'-biphenyl])-4-yl)-2-phenylpyrimidine (P2a): The silica column was performed using $\mathrm{CH}_{2} \mathrm{Cl}_{2}$ /hexanes 1:1 $\left(\mathrm{R}_{\mathrm{f}}=0.60\right)$. Light Yellow Solid. Isolated yield $=0.193 \mathrm{~g}(45 \%) .{ }^{1} \mathrm{H}$ NMR $\left(\mathrm{CDCl}_{3}, 500 \mathrm{MHz}, 22{ }^{\circ} \mathrm{C}\right): \delta 8.76-8.74(\mathrm{~m}, 2 \mathrm{H}), 8.32(\mathrm{~m}, 2 \mathrm{H}), 8.22-$ $8.20(\mathrm{~m}, 2 \mathrm{H}), 7.92(\mathrm{~s}, 1 \mathrm{H}), 7.76(\mathrm{~m}, 2 \mathrm{H}), 7.70-7.68(\mathrm{~m}, 2 \mathrm{H}), 7.59-7.55(\mathrm{~m}, 3 \mathrm{H}), 7.52-7.49(\mathrm{~m}, 2 \mathrm{H})$, 7.44-7.38 (m, 3H), $2.55 \mathrm{ppm}(\mathrm{s}, 3 \mathrm{H}) .{ }^{13} \mathrm{C}\left\{{ }^{1} \mathrm{H}\right\} \mathrm{NMR}\left(\mathrm{CDCl}_{3}, 126 \mathrm{MHz}, 22{ }^{\circ} \mathrm{C}\right): \delta 164.4,164.2$, $163.9,143.5,142.5,140.4,138.3,136.4,133.9,130.7,129.0,128.6,128.5,127.9,127.7,127.6$, $127.5,127.2,126.1,109.5,15.3$ ppm $\left(C_{\mathrm{SMe}}-\mathrm{H}\right)$. HR-MS(ESI+) m/z calcd. For $\left[\mathrm{C}_{29} \mathrm{H}_{22} \mathrm{~N}_{2} \mathrm{~S}+\mathrm{H}^{+}\right]$ 431.1576 , found 431.1550 .

$N, N$-Dimethyl-4-(6-[1,1'-biphenyl])-4-yl)-2-phenylpyrimidin-4-yl)benzamine $\quad$ (P2c): The silica column was performed using $\mathrm{CH}_{2} \mathrm{Cl}_{2} /$ hexanes 8:2 $\left(\mathrm{R}_{\mathrm{f}}=0.65\right)$. Yellow Solid. Isolated yield $=0.196 \mathrm{~g}(46 \%) .{ }^{1} \mathrm{H} \mathrm{NMR}\left(\mathrm{CDCl}_{3}, 500 \mathrm{MHz}, 22{ }^{\circ} \mathrm{C}\right): \delta 8.73(\mathrm{~m}, 2 \mathrm{H}), 8.36(\mathrm{~m}, 2 \mathrm{H}), 8.27-8.25$ $(\mathrm{m}, 2 \mathrm{H}), 7.96(\mathrm{~s}, 1 \mathrm{H}), 7.78(\mathrm{~m}, 2 \mathrm{H}), 7.71-7.69(\mathrm{~m}, 2 \mathrm{H}), 7.56-7.48(\mathrm{~m}, 5 \mathrm{H})$, 7.42-7.39 (m, 1H), 6.85-6.83 (m, 2H), 3.09 ppm (s, 6H). ${ }^{13} \mathrm{C}\left\{{ }^{1} \mathrm{H}\right\} \mathrm{NMR}\left(\mathrm{CDCl}_{3}, 126 \mathrm{MHz}, 22{ }^{\circ} \mathrm{C}\right): \delta$ 164.7, 164.4, $163.7,152.4,143.3,140.7,138.8,137.1,130.5,129.0,128.6,128.5,127.9,127.8,127.7,127.3$, 124.9, 112.0, 108.6, 40.3 ppm. HR-MS(ESI+) m/z calcd. For $\left[\mathrm{C}_{30} \mathrm{H}_{25} \mathrm{~N}_{3}+\mathrm{H}\right]^{+} 428.2121$, found 428.2110.

Large-scale preparation of P2c: $N, N$-Dimethyl-4-(6-[1,1'-biphenyl])-4-yl)-2-phenylpyrimidin4-yl)benzamine (P2c) was also prepared on a larger (millimolar) scale using benzamidine hydrochloride (0.780 g, $5 \mathrm{mmol})$, 4-(dimethylamino)phenyl)methanol (0.832 g, $5.5 \mathrm{mmol}), 1$-(4biphenylyl)ethanol (1.983 g, $10 \mathrm{mmol})$ with $\mathrm{KO} t \mathrm{Bu}(1.403 \mathrm{~g}, 12.5 \mathrm{mmol})$ and 1 ( $0.025 \mathrm{~g}, 0.5$ mol\%). The same protocol was followed for work-up and isolation. Isolated yield $=0.853 \mathrm{~g}$ (40 $\%)$. 
4-(6-[1,1'-biphenyl])-4-yl)-2-phenyl-6-(pyren-1-yl)pyrimidine (P2d): The silica column was performed using $\mathrm{CH}_{2} \mathrm{Cl}_{2} /$ hexanes 1:1 $\left(\mathrm{R}_{\mathrm{f}}=0.44\right)$. White solid. Isolated yield $=0.152 \mathrm{~g}(30 \%) .{ }^{1} \mathrm{H}$ $\operatorname{NMR}\left(\mathrm{CDCl}_{3}, 500 \mathrm{MHz}, 22{ }^{\circ} \mathrm{C}\right): \delta 8.81-8.79(\mathrm{~m}, 2 \mathrm{H}), 8.70\left(\mathrm{~d}, J_{H H}=10 \mathrm{~Hz}, 1 \mathrm{H}\right), 8.44-8.42(\mathrm{~m}$, 2H), 8.37-8.32 (m, 2H), 8.27-8.24 (m, 2H), 8.19-8.14 (m, 3H), 8.09 (s, 1H), 8.08-8.05 (m, 1H), $7.81(\mathrm{~m}, 2 \mathrm{H}), 7.70(\mathrm{~m}, 2 \mathrm{H}), 7.59-7.54(\mathrm{~m}, 3 \mathrm{H}), 7.52-7.49(\mathrm{~m}, 2 \mathrm{H}), 7.43-7.40 \mathrm{ppm}(\mathrm{m}, 1 \mathrm{H}) .{ }^{13} \mathrm{C}\left\{{ }^{1} \mathrm{H}\right\}$ $\operatorname{NMR}\left(\mathrm{CDCl}_{3}, 126 \mathrm{MHz}, 22{ }^{\circ} \mathrm{C}\right): \delta 167.9,164.7,163.9,143.9,140.5,138.3,136.3,133.9,132.5$, $131.5,131.0,130.9,129.1,128.8,128.7,128.0,127.9,127.8,127.7,127.5,127.4,126.4,125.9$, 125.6, 125.3, 125.0, 124.9, $124.8,116.0 \mathrm{ppm}\left(C_{\mathrm{Ar}} \mathrm{H}\right)$. HR-MS(ESI+) m/z calcd. For $\left[\mathrm{C}_{38} \mathrm{H}_{24} \mathrm{~N}_{2}+\mathrm{H}\right]^{+}$509.2012, found 509.1990.

4-([2,2':5',2'"-terthiophen]-5-yl)-6-(6-[1,1'-biphenyl])-4-yl)-2-phenylpyrimidine (P2e): The silica column was performed using $\mathrm{CH}_{2} \mathrm{Cl}_{2}$ /hexanes 3:2 $\left(\mathrm{R}_{\mathrm{f}}=0.60\right)$. Yellow Solid. Isolated yield $=0.177 \mathrm{~g}(32 \%) .{ }^{1} \mathrm{H} \mathrm{NMR}\left(\mathrm{CDCl}_{3}, 500 \mathrm{MHz}, 22{ }^{\circ} \mathrm{C}\right): \delta 8.70-8.68(\mathrm{~m}, 2 \mathrm{H}), 8.33-8.31(\mathrm{~m}, 2 \mathrm{H})$, $7.81(\mathrm{~s}, 1 \mathrm{H}), 7.78-7.76(\mathrm{~m}, 3 \mathrm{H}), 7.69-7.68(\mathrm{~m}, 2 \mathrm{H})$, 7.57-7.48 (m, 5H), 7.43-7.40 (m, 1H), 7.23$7.21(\mathrm{~m}, 4 \mathrm{H}), 7.12(\mathrm{~m}, 1 \mathrm{H}), 7.05-7.03 \mathrm{ppm}(\mathrm{m}, 1 \mathrm{H}) .{ }^{13} \mathrm{C}\left\{{ }^{1} \mathrm{H}\right\} \mathrm{NMR}\left(\mathrm{CDCl}_{3}, 126 \mathrm{MHz}, 22{ }^{\circ} \mathrm{C}\right): \delta$ $164.6,164.1,159.4,143.7,141.9,141.4,140.5,137.9,137.5,137.1,136.3,135.9,130.9,129.1$, $128.6,128.1,128.1,128.0,127.9,127.8,127.7,127.3,125.4,124.9,124.7,124.6,124.5$ ppm $\left(C_{\mathrm{Ar}} \mathrm{H}\right) . \mathrm{HR}-\mathrm{MS}(\mathrm{ESI}+) \mathrm{m} / \mathrm{z}$ calcd. For $\left[\mathrm{C}_{34} \mathrm{H}_{22} \mathrm{~N}_{2} \mathrm{~S}_{3}+\mathrm{H}\right]^{+} 555.1018$, found 555.1028.

4-(6-[1,1'-biphenyl])-4-yl)-2-phenylpyrimidin-4-yl)-9-ethyl-9H-carbazole (P2f): The silica column was performed using $\mathrm{CH}_{2} \mathrm{Cl}_{2} /$ hexanes 8:2 $\left(\mathrm{R}_{\mathrm{f}}=0.89\right)$. White solid. Isolated yield $=0.251$ $\mathrm{g}(50 \%) .{ }^{1} \mathrm{H} \mathrm{NMR}\left(\mathrm{CDCl}_{3}, 500 \mathrm{MHz}, 22{ }^{\circ} \mathrm{C}\right): \delta 9.02(\mathrm{~s}, 1 \mathrm{H}), 8.84-8.82(\mathrm{~m}, 2 \mathrm{H}), 8.46-8.44(\mathrm{~m}$, 1H), $8.40(\mathrm{~m}, 2 \mathrm{H}), 8.30-8.28(\mathrm{~m}, 1 \mathrm{H}), 8.09(\mathrm{~s}, 1 \mathrm{H}), 7.81-7.79(\mathrm{~m}, 2 \mathrm{H}), 7.72(\mathrm{~m}, 2 \mathrm{H}), 7.64-7.44$ $(\mathrm{m}, 9 \mathrm{H}), 7.37-7.34(\mathrm{~m}, 1 \mathrm{H}), 4.38-4.34(\mathrm{~m}, 2 \mathrm{H}), 1.48-1.45 \mathrm{ppm}(\mathrm{m}, 3 \mathrm{H}) .{ }^{13} \mathrm{C}\left\{{ }^{1} \mathrm{H}\right\} \mathrm{NMR}\left(\mathrm{CDCl}_{3}\right.$, $\left.126 \mathrm{MHz}, 22{ }^{\circ} \mathrm{C}\right): \delta 165.3,164.3,163.8,143.3,141.7,140.6,140.5,138.6,136.7,130.6,129.0$, 
$128.6,128.5,128.2,127.9,127.8,127.6,127.3,126.2,125.2,123.4,123.3,120.9,119.8,119.6$, 109.6, 108.9, 108.7, 37.8, 13.9 ppm $\left(C_{\text {ethyl- }} \mathrm{CH}_{3}\right)$. HR-MS(ESI+) m/z calcd. For $\left[\mathrm{C}_{36} \mathrm{H}_{27} \mathrm{~N}_{3}+\mathrm{H}\right]^{+}$ 502.2278, found 502.2247.

$N, N$-Biphenyl-4-(6-[1,1'-biphenyl])-4-yl)-2-phenylpyrimidin-4-yl)benzamine $\quad$ (P2g): The silica column was performed using $\mathrm{CH}_{2} \mathrm{Cl}_{2} /$ hexanes 1:1 $\left(\mathrm{R}_{\mathrm{f}}=0.50\right)$. White solid. Isolated yield $=$ $0.237 \mathrm{~g}(43 \%) .{ }^{1} \mathrm{H}$ NMR $\left(\mathrm{CDCl}_{3}, 500 \mathrm{MHz}, 22{ }^{\circ} \mathrm{C}\right): \delta 8.75-8.73(\mathrm{~m}, 2 \mathrm{H}), 8.37-8.36(\mathrm{~m}, 2 \mathrm{H}), 8.20-$ $8.18(\mathrm{~m}, 2 \mathrm{H}), 7.97(\mathrm{~s}, 1 \mathrm{H}), 7.80-7.78(\mathrm{~m}, 2 \mathrm{H}), 7.71-7.69(\mathrm{~m}, 2 \mathrm{H})$, 7.56-7.48 (m, 5H), 7.42-7.40 (m, $1 \mathrm{H}), 7.35-7.32(\mathrm{~m}, 4 \mathrm{H}), 7.21-7.20(\mathrm{~m}, 6 \mathrm{H}), 7.14-7.11 \mathrm{ppm}(\mathrm{m}, 2 \mathrm{H}) .{ }^{13} \mathrm{C}\left\{{ }^{1} \mathrm{H}\right\} \mathrm{NMR}\left(\mathrm{CDCl}_{3}\right.$, $\left.126 \mathrm{MHz}, 22{ }^{\circ} \mathrm{C}\right): \delta 164.5,164.3,164.1,150.6,147.3,143.6,140.5,138.5,136.7,130.7,130.6$ $129.6,129.1,128.6,128.5,128.4,127.9,127.8,127.7,127.3,125.4,124.0,122.2,109.4$ ppm. HRMS(ESI + ) m/z calcd. For $\left[\mathrm{C}_{40} \mathrm{H}_{29} \mathrm{~N}_{3}+\mathrm{H}\right]^{+} 552.2434$, found 552.2429.

4-(-2-phenylpyrimidin-4-yl)-6-(pyren-1-yl)9-ethyl-9H-carbazole (P3f): The silica column was performed using $\mathrm{CH}_{2} \mathrm{Cl}_{2} /$ hexanes 1:1 $\left(\mathrm{R}_{\mathrm{f}}=0.71\right)$. Yellow solid. Isolated yield $=0.236 \mathrm{~g}(43 \%)$. ${ }^{1} \mathrm{H} \mathrm{NMR}\left(\mathrm{CDCl}_{3}, 500 \mathrm{MHz}, 22{ }^{\circ} \mathrm{C}\right): \delta 9.11(\mathrm{~m}, 1 \mathrm{H}), 8.83(\mathrm{~m}, 1 \mathrm{H}), 8.74\left(\mathrm{~m}, 1 \mathrm{H},{ }^{3} J_{\mathrm{HH}}=10 \mathrm{~Hz}\right)$, 8.54-8.52 (m, $1 \mathrm{H}), 8.41-8.39(\mathrm{~m}, 1 \mathrm{H}), 8.35-8.33(\mathrm{~m}, 1 \mathrm{H}), 8.27-8.24(\mathrm{~m}, 3 \mathrm{H}), 8.19-8.15$ (overlapped m, 4H), 8.08-8.05 (m, 1H), 7.61-7.52 (m, 5H), 7.48-7.46 (m, 1H), 7.33-7.30 (m, 1H), 4.46-4.42 (m, 2H), 1.52-1.49 ppm (m, 3H). ${ }^{13} \mathrm{C}\left\{{ }^{1} \mathrm{H}\right\} \mathrm{NMR}\left(\mathrm{CDCl}_{3}, 126 \mathrm{MHz}, 22{ }^{\circ} \mathrm{C}\right): \delta 167.5$, 165.1, 164.6, 141.9, 140.8, 138.6, 134.4, 132.4, 131.5, 131.1, 130.7, 129.1, 128.8, 128.7, 128.6, $128.2,127.7,127.6,126.4,126.3,125.8,125.5,125.4,125.3,125.0,124.9,124.9,123.7,123.4$ $120.9,120.1,119.7,115.6,109.0,108.9,37.9,14.0 \mathrm{ppm}$. HR-MS(ESI+) m/z calcd. For $\left[\mathrm{C}_{40} \mathrm{H}_{27} \mathrm{~N}_{3}+\mathrm{H}\right]^{+} 550.2278$, found 550.2273 . 
N,N-Biphenyl-6-(pyren-1-yl)-2-phenyl-4-pyrimidinyl]benzenamine (P3g): The silica column was performed using $\mathrm{CH}_{2} \mathrm{Cl}_{2} /$ hexanes 3:2 $\left(\mathrm{R}_{\mathrm{f}}=0.67\right)$. Yellow Solid. Isolated yield $=0.233 \mathrm{~g}(39$ \%). ${ }^{1} \mathrm{H} \mathrm{NMR}\left(\mathrm{CDCl}_{3}, 500 \mathrm{MHz}, 22{ }^{\circ} \mathrm{C}\right): \delta 8.77-8.75(\mathrm{~m}, 2 \mathrm{H}), 8.69-8.67\left(\mathrm{~m}, 1 \mathrm{H},{ }^{3} J_{\mathrm{HH}}=10 \mathrm{~Hz}\right)$, 8.35-8.30 (m, 2H), 8.26-8.21 (m, 4H), 8.17-8.13 (m, 3H), 8.07-8.04 (m, 1H), 7.96 (s, 1H), 7.56$7.51(\mathrm{~m}, 3 \mathrm{H}), 7.35-7.31(\mathrm{~m}, 4 \mathrm{H}), 7.21-7.20(\mathrm{~m}, 6 \mathrm{H}), 7.14-7.11 \mathrm{ppm}(\mathrm{m}, 2 \mathrm{H}) .{ }^{13} \mathrm{C}\left\{{ }^{1} \mathrm{H}\right\} \mathrm{NMR}$ $\left(\mathrm{CDCl}_{3}, 126 \mathrm{MHz}, 2{ }^{\circ} \mathrm{C}\right): \delta 167.5,164.5,163.8,150.7,147.2,138.4,134.2,132.4,131.5,131.0$ $130.8,130.2,129.6,129.0,128.7,128.6,128.5,128.4,127.6,127.5,126.4,125.8,125.5,125.3$, 125.0, 124.9, 124.8, 124.1, 122.1, $115.2 \mathrm{ppm}\left(C_{\mathrm{Ar}}\right)$. HR-MS(ESI+) m/z calcd. For $\left[\mathrm{C}_{44} \mathrm{H}_{29} \mathrm{~N}_{3}+\mathrm{H}\right]^{+}$ 600.2434 , found 600.2420 .

2,4-diphenyl-6-(pyren-1-yl)pyrimidine (P4d): The silica column was performed using $\mathrm{CH}_{2} \mathrm{Cl}_{2} /$ hexanes 1:1 $\left(\mathrm{R}_{\mathrm{f}}=0.61\right)$. Light yellow solid. Isolated yield $=0.160 \mathrm{~g}(37 \%) .{ }^{1} \mathrm{H}$ NMR $\left(\mathrm{CDCl}_{3}, 500 \mathrm{MHz}, 22{ }^{\circ} \mathrm{C}\right): \delta 8.83-8.81(\mathrm{~m}, 2 \mathrm{H}), 8.70-8.68(\mathrm{~d}, 1 \mathrm{H}), 8.37-8.35(\mathrm{~m}, 2 \mathrm{H}), 8.33(\mathrm{~s}$, 1H), 8.31-8.29 (m, 1H), 8.26-8.22 (m, 2H), 8.17-8.12 (m, 3H), 8.07-8.04 (overlapped m, 2H), 7.61-7.56 ppm (m, 3H). ${ }^{13} \mathrm{C}\left\{{ }^{1} \mathrm{H}\right\} \mathrm{NMR}\left(\mathrm{CDCl}_{3}, 126 \mathrm{MHz}, 22{ }^{\circ} \mathrm{C}\right): \delta 167.8,164.6,164.3,138.3$, $137.5,133.9,132.4,131.5,131.0,130.9,130.8,129.1,129.0,128.8,128.7,128.6,127.6,127.5$, $127.4,126.3,125.9,125.6,125.3,124.9,124.8,124.7,116.0 \mathrm{ppm}\left(C_{\mathrm{Ar}} \mathrm{H}\right) . \mathrm{HR}-\mathrm{MS}(\mathrm{ESI}+) \mathrm{m} / \mathrm{z}$ calcd. For $\left[\mathrm{C}_{30} \mathrm{H}_{20} \mathrm{~N}_{2}+\mathrm{H}\right]^{+} 433.1699$, found 433.1716 .

4-(anthracene-9-yl)-6-phenyl-2-(p-tolyl)pyrimidine (P4h): The silica column was performed using $\mathrm{CH}_{2} \mathrm{Cl}_{2} /$ hexanes 1:1 $\left(\mathrm{R}_{\mathrm{f}}=0.60\right)$. Yellow solid. Isolated yield $=0.139 \mathrm{~g}(33 \%) .{ }^{1} \mathrm{H}$ NMR $\left(\mathrm{CDCl}_{3}, 500 \mathrm{MHz}, 2{ }^{\circ} \mathrm{C}\right): \delta 8.61-8.58(\mathrm{~m}, 3 \mathrm{H}), 8.32$ (br m, 2H), 8.11-8.09 (m, 2H), 7.83-7.80 (overlapped m, 3H), $7.55(\mathrm{~m}, 3 \mathrm{H}), 7.51-7.49(\mathrm{~m}, 2 \mathrm{H}), 7.43-7.40(\mathrm{~m}, 2 \mathrm{H}), 7.31(\mathrm{~m}, 2 \mathrm{H}), 2.44$ ppm $(\mathrm{s}, 3 \mathrm{H}) .{ }^{13} \mathrm{C}\left\{{ }^{1} \mathrm{H}\right\} \mathrm{NMR}\left(\mathrm{CDCl}_{3}, 126 \mathrm{MHz}, 22{ }^{\circ} \mathrm{C}\right): \delta 167.2,165.3,164.1,141.2,137.3,135.5$, 
133.6, 131.6, 131.1, 129.7, 129.4, 129.1, 128.8, 128.7, 128.4, 127.5, 126.5, 125.9, 125.5, 117.4,

$21.7 \mathrm{ppm}\left(\mathrm{C}_{\mathrm{Me}-\mathrm{H}}\right)$. HR-MS(ESI+) m/z calcd. For $\left[\mathrm{C}_{31} \mathrm{H}_{22} \mathrm{~N}_{2}+\mathrm{H}\right]^{+} 423.1856$, found 423.1838 .

\section{X-ray Crystallography}

X-ray crystal structure data were collected from multi-faceted crystals of suitable size and quality selected from a representative sample of crystals of the same habit using an optical microscope. In each case, crystals were mounted on MiTiGen loops with data collection carried out in a cold stream of nitrogen $\left(150 \mathrm{~K}\right.$; Bruker D8 QUEST ECO; Mo $\mathrm{K}_{\alpha}$ radiation). All diffractometer manipulations were carried out using Bruker APEX3 software. ${ }^{55}$ Structure solution and refinement was carried out using XS, XT and XL software, embedded within the Bruker SHELXTL suite. ${ }^{56}$ For each structure, the absence of additional symmetry was confirmed using ADDSYM incorporated in the PLATON program. ${ }^{57}$ CCDC Nos. 2018078-2018079 contain the supplementary crystallographic data for this paper. The data can be obtained free of charge from The Cambridge Crystallographic Data Centre via www.ccdc.cam.ac.uk/structures.

Crystal structure data for P1c (CCDC No. 2018078): X-ray quality crystals were grown after 3 days at $-10{ }^{\circ} \mathrm{C}$ from a solution of the compound in a mixture of acetone and pentane. Crystal structure parameters: $\mathrm{C}_{29} \mathrm{H}_{25} \mathrm{~N}_{3} \mathrm{O} 431.52 \mathrm{~g} / \mathrm{mol}$, monoclinic, space group $P 2{ }_{1} / \mathrm{c} ; \mathrm{a}=9.5603(5) \AA$, $\mathrm{b}=15.4396(7) \AA, \mathrm{c}=14.7968(7) \AA, \alpha=90^{\circ}, \beta=92.646(2)^{\circ}, \gamma=90^{\circ}, \mathrm{V}=2181.79(18) \AA^{3} ; \mathrm{Z}=2$, $\rho_{\text {calcd }}=1.314 \mathrm{~g} \mathrm{~cm}^{-3} ;$ crystal dimensions $0.44 \times 0.27 \times 0.18 \mathrm{~mm}^{3} ; \theta_{\max }=33.222^{\circ} ; 76282$ reflections, 8105 independent $\left(\mathrm{R}_{\mathrm{int}}=0.0544\right)$, direct methods; absorption coeff $\left(\mu=0.081 \mathrm{~mm}^{-1}\right)$, absorption correction semi-empirical from equivalents (SADABS); refinement (against $\mathrm{F}_{0}{ }^{2}$ ) with SHELXTL V6.1, 301 parameters, 0 restraints, $\mathrm{R}_{1}=0.0661(I>2 \sigma)$ and $w \mathrm{R}_{2}=0.1665$ (all data), Goof $=1.029$, residual electron density 0.462 and -0.258 e $\AA^{-3}$. 
Crystal structure data for P3g (CCDC No. 2018079): X-ray quality crystals were grown over two days at $-10{ }^{\circ} \mathrm{C}$ from a solution of compound dissolved in a mixture of acetone and pentane. Crystal structure parameters: $\mathrm{C}_{44} \mathrm{H}_{29} \mathrm{~N}_{3} 599.70 \mathrm{~g} / \mathrm{mol}$, triclinic, space group $P-1 ; \mathrm{a}=11.7391(6) \AA, \mathrm{b}=$ 12.2007(7) $\AA, \mathrm{c}=13.0911(7) \AA, \alpha=102.3551(18)^{\circ}, \beta=103.2875(18)^{\circ}, \gamma=104.9579(18)^{\circ}, \mathrm{V}=$ $1686.84(16) \AA^{3} ; \mathrm{Z}=2, \rho_{\text {calcd }}=1.181 \mathrm{~g} \mathrm{~cm}^{-3} ;$ crystal dimensions $0.270 \times 0.235 \times 0.215 \mathrm{~mm}^{3} ; \theta_{\max }$ $=27.548^{\circ} ; 46030$ reflections, 7737 independent $\left(\mathrm{R}_{\text {int }}=0.0457\right)$, direct methods; absorption coeff

$\left(\mu=0.069 \mathrm{~mm}^{-1}\right)$, absorption correction semi-empirical from equivalents (SADABS); refinement (against $\left.\mathrm{F}_{\mathrm{o}}{ }^{2}\right)$ with SHELXTL V6.1, 424 parameters, 0 restraints, $\mathrm{R}_{1}=0.0610(I>2 \sigma)$ and $w \mathrm{R}_{2}=$ 0.1469 (all data), Goof $=1.035$, residual electron density 0.298 and $-0.343 \mathrm{e} \AA^{-3}$.

\section{ASSOCIATED CONTENT}

Supporting Information. Additional UV-Vis absorption and emission spectra; computational data tables; cyclic voltammograms; multi-nuclear NMR and HR-MS spectra of all new compounds; crystallographic information files containing all X-ray data. CCDC 20180782018079 contain the supplementary crystallographic data for this paper. The data can be obtained free of charge from The Cambridge Crystallographic Data Center via www.ccdc.cam.ac.uk/structures.

The following files are available free of charge:

Supporting Information File (PDF)

Combined Crystallographic Information File (CIF) 


\section{AUTHOR INFORMATION}

\section{Corresponding Author}

David E. Herbert (david.herbert@umanitoba.ca)

\section{ORCIDs}

Rajarshi Mondal: 0000-0002-6819-6690

Issiah B. Lozada: 0000-0002-1689-2918

Olha Stotska: 0000-0003-3689-4758

David E. Herbert: 0000-0001-8190-2468

\section{Author Contributions}

The manuscript was written through contributions of all authors. All authors have given approval to the final version of the manuscript.

\section{Conflicts of Interest}

There are no conflicts of interest to declare.

\section{ACKNOWLEDGMENTS}

The following sources of funding are gratefully acknowledged: Natural Sciences Engineering Research Council of Canada for a Discovery Grant to DEH (RGPIN-2014-03733); the Canadian Foundation for Innovation and Research Manitoba for an award in support of an X-ray diffractometer (CFI \#32146); the University of Manitoba for the Bert \& Lee Friesen Graduate Scholarship (IBL); Mitacs for a Globalink Research Award (OS); and Compute Canada for access to computational resources. 


\section{REFERENCES}

(1) Johnson, T. B.; Hahn, D. A. Pyrimidines: Their Amino and Aminoöxy Derivatives. Chem. Rev. 1933, 13, 193-303.

(2) Ono, A.; Torigoe, H.; Tanaka, Y.; Okamoto, I. Binding of Metal Ions by Pyrimidine Base Pairs in DNA Duplexes. Chem. Soc. Rev. 2011, 40, 5855-5866.

(3) Schenone, S.; Radi, M.; Musumeci, F.; Brullo, C.; Botta, M. Biologically Driven Synthesis of Pyrazolo[3,4-d]Pyrimidines as Protein Kinase Inhibitors: An Old Scaffold as a New Tool for Medicinal Chemistry and Chemical Biology Studies. Chem. Rev. 2014, 114, 71897238 .

(4) Achelle, S.; Rodriguez-Lopez, J.; Guen, F. R. Photoluminescence Properties of Aryl-, Arylvinyl-, and Arylethynylpyrimidine Derivatives. ChemistrySelect 2018, 3, 1852-1886.

(5) Bureš, F. Fundamental Aspects of Property Tuning in Push-Pull Molecules. RSC Adv. 2014, 4, 58826-58851.

(6) Hughes, G.; Wang, C.; Batsanov, A. S.; Fern, M.; Frank, S.; Bryce, M. R.; Perepichka, I. F.; Monkman, A. P.; Lyons, B. P. New Pyrimidine- and Fluorene-Containing Oligo(Arylene)s: Synthesis, Crystal Structures, Optoelectronic Properties and a Theoretical Study. Org. Biomol. Chem. 2003, 1, 3069-3077.

(7) Berner, D.; Klein, C.; Nazeeruddin, M. K.; De Angelis, F.; Castellani, M.; Bugnon, P.; Scopelliti, R.; Zuppiroli, L.; Graetzel, M. Efficient Blue Light-Emitting Diodes Based on a Classical "Push-Pull" Architecture Molecule 4,4'-Di-(2-(2,5-Dimethoxyphenyl)Ethenyl)2,2'-Bipyridine. J. Mater. Chem. 2006, 16, 4468-4474.

(8) Shaker, M.; Lee, J.-H.; Trinh, C. K.; Kim, W.; Lee, K.; Lee, J.-S. A Facile Method to Synthesize [A' (D'AD) $)_{2}$-Based Push-Pull Small Molecules for Organic Photovoltaics. RSC $A d v$. 2015, 5, 66005-66012.

(9) Raheem, A. A.; Kamaraj, S.; Sannasi, V.; Praveen, C. New D- $\pi$-A Push-Pull Chromophores as Low Band Gap Molecular Semiconductors for Organic Small Molecule Solar Cell Applications. Org. Chem. Front. 2018, 5, 777-787.

(10) Song, C.; Wang, Z.; Li, J.; Chen, Y.; Zhao, F.; Zhang, H. Extension of $\pi$-Conjugation and Enhancement of Electron-Withdrawing Ability at Terminal Indenedione for A- $\pi$-D- $\pi$-A Small Molecules for Application in Organic Solar Cells. Org. Electron. 2020, 81, 105679.

(11) Kumar, C.; Raheem, A. A.; Pandian, K.; Nandakumar, V.; Shanmugam, R.; Praveen, C. Fine-Tuning the Optoelectronic Chattels of Fluoreno-Thiophene Centred Molecular Semiconductors through Symmetric and Asymmetric Push-Pull Switch. New J. Chem. 2019, 43, 7015-7027. 
(12) Schomaker, J. M.; Delia, T. J. Arylation of Halogenated Pyrimidines via a Suzuki Coupling Reaction. J. Org. Chem. 2001, 66, 7125-7128.

(13) Hockova, D.; Holy, A.; Masojidkova, M.; Votruba, I. An Efficient Synthesis of Cytostatic Mono and Bis-Alkynylpyrimidine Derivatives by the Sonogashira Cross-Coupling Reactions of 2,4-Diamino-6-Iodopyrimidine and 2-Amino-4,6-Dichloropyrimidine. Tetrahedron 2004, 60, 4983-4987.

(14) Saygili, N.; Batsanov, A. S.; Bryce, M. R. 5-Pyrimidylboronic Acid and 2-Methoxy-5Pyrimidylboronic Acid: New Heteroarylpyrimidine Derivatives via Suzuki Cross-Coupling Reactions. Org. Biomol. Chem. 2004, 2, 852-857.

(15) Stanetty, P.; Hattinger, G.; Schnuerch, M.; Mihovilovic, M. D. Novel and Efficient Access to Phenylamino-Pyrimidine Type Protein Kinase C Inhibitors Utilizing a Negishi CrossCoupling Strategy. J. Org. Chem. 2005, 70, 5215-5220.

(16) Delia, T. J.; Schomaker, J. M.; Kalinda, A. S. The Synthesis of Substituted Phenylpyrimidines via Suzuki Coupling Reactions. J. Heterocycl. Chem. 2006, 43, 127131.

(17) Dufresne, S.; Hanan, G. S.; Skene, W. G. Preparation, Photophysics, and Electrochemistry of Segmented Comonomers Consisting of Thiophene and Pyrimidine Units: New Monomers for Hybrid Copolymers. J. Phys. Chem. B 2007, 111, 11407-11418.

(18) Kato, S.-I.; Yamada, Y.; Hiyoshi, H.; Umezu, K.; Nakamura, Y. Series of CarbazolePyrimidine Conjugates: Syntheses and Electronic, Photophysical, and Electrochemical Properties. J. Org. Chem. 2015, 80, 9076-9090.

(19) Pérez-Caaveiro, C.; Oliva, M. M.; López Navarrete, J. T.; Pérez Sestelo, J.; Martínez, M. M.; Sarandeses, L. A. Synthesis of D-A-A and D-A-D Pyrimidine $\pi$-Systems Using Triorganoindium Reagents: Optical, Vibrational, and Electrochemical Studies. J. Org. Chem. 2019, 84, 8870-8885.

(20) Mueller, T. J. J.; Braun, R.; Ansorge, M. A Novel Three-Component One-Pot Pyrimidine Synthesis Based Upon a Coupling-Isomerization Sequence. Org. Lett. 2000, 2, 1967-1970.

(21) Ghosh, U.; Katzenellenbogen, J. A. A Convenient Method for the Preparation of Highly Substituted Pyrimidines: Synthesis of Tri- and Tetra-Substituted Pyrimidines from 1,3Dicarbonyl Compounds and $N, N, N^{\prime}$-Tris-(Trimethylsilyl)Amidines. J. Heterocycl. Chem. 2002, 39, 1101-1104.

(22) Martinez, R.; Ramon, D. J.; Yus, M. $\mathrm{RuCl}_{2}(\mathrm{DMSO})_{4}$ Catalyzes the Solvent-Free Indirect Friedlaender Synthesis of Polysubstituted Quinolines from Alcohols. Eur. J. Org. Chem. 2007, 1599-1605. 
(23) Deibl, N.; Ament, K.; Kempe, R. A Sustainable Multicomponent Pyrimidine Synthesis. J. Am. Chem. Soc. 2015, 137, 12804-12807.

(24) Mastalir, M.; Glatz, M.; Pittenauer, E.; Allmaier, G.; Kirchner, K. Sustainable Synthesis of Quinolines and Pyrimidines Catalyzed by Manganese PNP Pincer Complexes. J. Am. Chem. Soc. 2016, 138, 15543-15546.

(25) Deibl, N.; Kempe, R. Manganese-Catalyzed Multicomponent Synthesis of Pyrimidines from Alcohols and Amidines. Angew. Chem., Int. Ed. 2017, 56, 1663-1666.

(26) Maji, M.; Kundu, S. Cooperative Ruthenium Complex Catalyzed Multicomponent Synthesis of Pyrimidines. Dalton Trans. 2019, 48, 17479-17487.

(27) Mondal, R.; Sinha, S.; Das, S.; Chakraborty, G.; Paul, N. D. Iron Catalyzed Synthesis of Pyrimidines Under Air. Adv. Synth. Catal. 2020, 362, 594-600.

(28) Chakraborty, G.; Sikari, R.; Mondal, R.; Mandal, S.; Paul, N. D. Nickel-Catalyzed Synthesis of Pyrimidines via Dehydrogenative Functionalization of Alcohols. Asian J. Org. Chem. 2020, 9, 431-436.

(29) Sultana Poly, S.; Siddiki, S. M. A. H.; Touchy, A. S.; Ting, K. W.; Toyao, T.; Maeno, Z.; Kanda, Y.; Shimizu, K. Acceptorless Dehydrogenative Synthesis of Pyrimidines from Alcohols and Amidines Catalyzed by Supported Platinum Nanoparticles. ACS Catal. 2018, $8,11330-11341$.

(30) Mondal, R.; Herbert, D. E. Synthesis of Pyridines, Quinolines, and Pyrimidines via Acceptorless Dehydrogenative Coupling Catalyzed by a Simple Bidentate $P^{\wedge} N$ Ligand Supported Ru Complex. Organometallics 2020, 39, 1310-1317.

(31) Lipunova, G. N.; Nosova, E. V.; Charushin, V. N.; Chupakhin, O. N. Functionalized Quinazolines and Pyrimidines for Optoelectronic Materials. Curr. Org. Synth. 2018, 15, 793-814.

(32) Jones, R. N. The Ultraviolet Absorption Spectra of Anthracene Derivatives. Chem. Rev. 1947, 41, 353-371.

(33) Itami, K.; Yamazaki, D.; Yoshida, J. Pyrimidine-Core Extended $\pi$-Systems: General Synthesis and Interesting Fluorescent Properties. J. Am. Chem. Soc. 2004, 126, 1539615397.

(34) Korepanov, V. I.; Sedlovets, D. M. An Asymmetric Fitting Function for Condensed-Phase Raman Spectroscopy. Analyst 2018, 143, 2674-2679.

(35) Hansch, C.; Leo, A.; Taft, R. W. A Survey of Hammett Substituent Constants and Resonance and Field Parameters. Chem. Rev. 1991, 91, 165-195. 
(36) Botek, E.; Champagne, B.; Gangopadhyay, P.; Persoons, A.; Verbiest, T. Theoretical Evaluation of the Faraday Effect in Organic Compounds. Comput. Lett. 2007, 3, 193-200.

(37) Segawa, H.; Takehara, C.; Honda, K.; Shimidzu, T.; Asahi, T.; Mataga, N. Photoinduced Electron-Transfer Reactions of Porphyrin Heteroaggregates: Energy Gap Dependence of an Intradimer Charge Recombination Process. J. Phys. Chem. 1992, 96, 503-506.

(38) Lever, A. B. P. Charge Transfer Spectra of Transition Metal Complexes. J. Chem. Educ. 1974, 51,612 .

(39) Safarzadeh-Amiri, A.; Thompson, M.; Krull, U. J. Trans-4-Dimethylamino-4'-(1Oxobutyl)Stilbene: A New Fluorescent Probe of the Bilayer Lipid Membrane. $J$. Photochem. Photobiol. A 1989, 47, 299-308.

(40) Diwu, Z.; Lu, Y.; Zhang, C.; Klaubert, D. H.; Haugland, R. P. Fluorescent Molecular Probes II. The Synthesis, Spectral Properties and Use of Fluorescent Solvatochromic Dapoxyl Dyes. Photochem. Photobiol. 1997, 66, 424-431.

(41) Mondal, R.; Lozada, I. B.; Davis, R. L.; Williams, J. A. G.; Herbert, D. E. Site-Selective Benzannulation of $N$-Heterocycles in Bidentate Ligands Leads to Blue-Shifted Emission from $\left[\left(P^{\wedge} N\right) \mathrm{Cu}\right]_{2}(\mu-\mathrm{X})_{2}$ Dimers. Inorg. Chem. 2018, 57, 4966-4978.

(42) Brunel, F.; Lautard, C.; di Giorgio, C.; Garzino, F.; Raimundo, J.-M.; Bolla, J.-M.; Camplo, M. Antibacterial Activities of Mono-, Di- and Tri-Substituted Triphenylamine-Based Phosphonium Ionic Liquids. Bioorg. Med. Chem. Lett. 2018, 28, 926-929.

(43) Cheng, J.; Liang, X.; Cao, Y.; Guo, K.; Wong, W.-Y. Aldehyde End-Capped Terthiophene with Aggregation-Induced Emission Characteristics. Tetrahedron 2015, 71, 5634-5639.

(44) Frisch, M. J.; Trucks, G. W.; Schlegel, H. B.; Scuseria, G. E.; Robb, M. A.; Cheeseman, J. R.; Scalmani, G.; Barone, V.; Petersson, G. A.; Nakatsuji, H.; Li, X.; Caricato, M.; Marenich, A. V.; Bloino, J.; Janesko, B. G.; Gomperts, R.; Mennucci, B.; Hratchian, H. P.; Ortiz, J. V.; Izmaylov, A. F.; Sonnenberg, J. L.; Williams-Young, D.; Ding, F.; Lipparini, F.; Egidi, F.; Goings, J.; Peng, B.; Petrone, A.; Henderson, T.; Ranasinghe, D.; Zakrzewski, V. G.; Gao, J.; Rega, N.; Zheng, G.; Liang, W.; Hada, M.; Ehara, M.; Toyota, K.; Fukuda, R.; Hasegawa, J.; Ishida, M.; Nakajima, T.; Honda, Y.; Kitao, O.; Nakai, H.; Vreven, T.; Throssell, K.; Montgomery, J. A.; Peralta, J. E.; Ogliaro, F.; Bearpark, M. J.; Heyd, J. J.; Brothers, E. N.; Kudin, K. N.; Staroverov, V. N.; Keith, T. A.; Kobayashi, R.; Normand, J.; Raghavachari, K.; Rendell, A. P.; Burant, J. C.; Iyengar, S. S.; Tomasi, J.; Cossi, M.; Millam, J. M.; Klene, M.; Adamo, C.; Cammi, R.; Ochterski, J. W.; Martin, R. L.; Morokuma, K.; Farkas, O.; Foresman, J. B.; Fox, D. J. Gaussian 16, Revision B.01; Gaussian 16, Revision B.01, Gaussian, Inc., Wallingford CT; Gaussian, Inc.: Wallingford CT, 2016.

(45) Scalmani, G.; Frisch, M. J. Continuous Surface Charge Polarizable Continuum Models of Solvation. I. General Formalism. J. Chem. Phys. 2010, 132, 114110/1-114110/15. 
(46) Grimme, S.; Ehrlich, S.; Goerigk, L. Effect of the Damping Function in Dispersion Corrected Density Functional Theory. J. Comput. Chem. 2011, 32, 1456-1465.

(47) Becke, A. D. Density-Functional Exchange-Energy Approximation with Correct Asymptotic Behavior. Phys. Rev. A 1988, 38, 3098-3100.

(48) Lee, C.; Yang, W.; Parr, R.G. Development of the Colle-Salvetti Correlation-Energy Formula into a Functional of the Electron Density. Phys. Rev. B Condens. Matter. 1988, 37 , $785-789$.

(49) Krishnan, R.; Binkley, J. S.; Seeger, R.; Pople, J. A. Self-Consistent Molecular Orbital Methods. XX. A Basis Set for Correlated Wave Functions. J. Chem. Phys. 1980, 72, 650654.

(50) Yu, H. S.; He, X.; Li, S. L.; Truhlar, D. G. MN15: A Kohn-Sham Global-Hybrid ExchangeCorrelation Density Functional with Broad Accuracy for Multi-Reference and SingleReference Systems and Noncovalent Interactions. Chem. Sci. 2016, 7, 5032-5051.

(51) Clark, T.; Chandrasekhar, J.; Spitznagel, G. W.; Schleyer, P. v R. Efficient Diffuse Function-Augmented Basis Sets for Anion Calculations. III. The 3-21 + G Basis Set for First-Row Elements, Lithium to Fluorine. J. Comput. Chem. 1983, 4, 294-301.

(52) Adamo, C.; Jacquemin, D. The Calculations of Excited-State Properties with TimeDependent Density Functional Theory. Chem. Soc. Rev. 2013, 42, 845-856.

(53) O’Boyle, N. M.; Tenderholt, A. L.; Langner, K. M. Software News and Updates Cclib: A Library for Package-Independent Computational Chemistry Algorithms. J. Comput. Chem. 2008, 29, 839-845.

(54) Hanwell, M. D.; Curtis, D. E.; Lonie, D. C.; Vandermeersch, T.; Zurek, E.; Hutchison, G. R. Avogadro: An Advanced Semantic Chemical Editor, Visualization, and Analysis Platform. J. Cheminf. 2012, 4, 17.

(55) Bruker-AXS. APEX3 V2016.1-0; Madison, Wisconsin, USA, 2016.

(56) Sheldrick, G. M. A Short History of SHELX. Acta Cryst. 2008, A64, 112-122.

(57) Spek, A. L. Structure Validation in Chemical Crystallography. Acta Cryst. 2009, D65, 148155. 
Table of Contents/Abstract Graphic

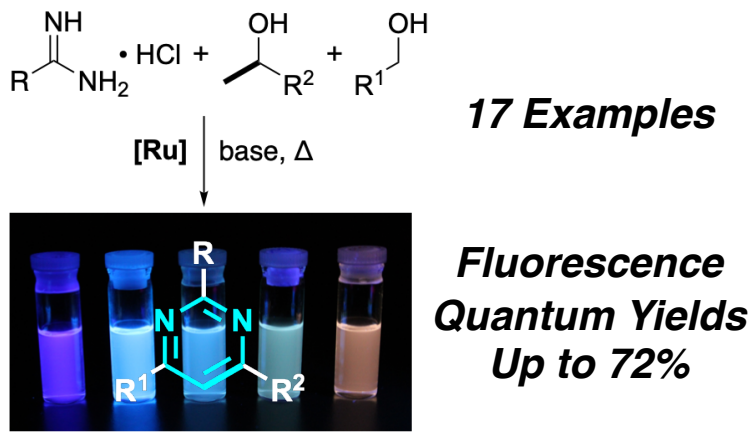

